IZA DP No. 10143

Mapping Experiences and Research about Unaccompanied Refugee Minors in Sweden and Other Countries

Aycan Çelikaksoy

Eskil Wadensjö

August 2016 


\title{
Mapping Experiences and Research about Unaccompanied Refugee Minors in Sweden and Other Countries
}

\author{
Aycan Çelikaksoy \\ SOFI, Stockholm University \\ Eskil Wadensjö \\ SOFI, Stockholm University \\ and IZA
}

Discussion Paper No. 10143

August 2016

\author{
IZA \\ P.O. Box 7240 \\ 53072 Bonn \\ Germany \\ Phone: +49-228-3894-0 \\ Fax: +49-228-3894-180 \\ E-mail: iza@iza.org
}

Any opinions expressed here are those of the author(s) and not those of IZA. Research published in this series may include views on policy, but the institute itself takes no institutional policy positions. The IZA research network is committed to the IZA Guiding Principles of Research Integrity.

The Institute for the Study of Labor (IZA) in Bonn is a local and virtual international research center and a place of communication between science, politics and business. IZA is an independent nonprofit organization supported by Deutsche Post Foundation. The center is associated with the University of Bonn and offers a stimulating research environment through its international network, workshops and conferences, data service, project support, research visits and doctoral program. IZA engages in (i) original and internationally competitive research in all fields of labor economics, (ii) development of policy concepts, and (iii) dissemination of research results and concepts to the interested public.

IZA Discussion Papers often represent preliminary work and are circulated to encourage discussion. Citation of such a paper should account for its provisional character. A revised version may be available directly from the author. 


\section{ABSTRACT \\ Mapping Experiences and Research about Unaccompanied Refugee Minors in Sweden and Other Countries*}

Many unaccompanied children have applied for asylum during the last few years, especially in 2015. These children face special challenges and risk being exploited due to their age and legal status. In this paper we survey research and otherwise documented experiences regarding this group of children. The main focus is on Sweden, the European country that has received most unaccompanied children but we also report on the experiences of other Nordic countries, a list of other EU member states, as well as USA and Turkey. We also try to summarize the main lessons for a policy to assist these children to integrate in the countries they have arrived to.

JEL Classification: F22, J13, J15, J61

Keywords: unaccompanied minors, separated refugee children, migration, reception policies, integration policies

Corresponding author:

Eskil Wadensjö

Swedish Institute for Social Research

University of Stockholm

SE-106 91 Stockholm

Sweden

E-mail: Eskil.Wadensjo@sofi.su.se

\footnotetext{
* This paper is a revised and extended version of a report prepared for the Swedish Ministry of Employment. We would like to thank Åsa Backlund, Riitta Eriksson, Christer Gerdes, Anders Hjern, Hélio Manica, Björn Ramel and Maren Zeller for their valuable opinions on a previous version.
} 


\section{An increasingly topical matter}

Children under the age of 18 who are separated from their parents or legal/customary guardians are defined as separated children and/or "unaccompanied minors". Identification of this group is of critical importance due to the special protection and assistance needs of this group (UNHCR, 2014). This population is considered 'vulnerable' due to their young age during the fleeing process combined with the fact that they are unaccompanied by their parents or legal guardians (Derluyn and Broekaert, 2008; Derluyn and Vervliet, 2012).

These children can face special challenges and risk being exploited due to their age and legal status. Thus, the global movement of unaccompanied and separated children presents challenges for children's rights and well-being. ${ }^{1}$

According to the UNHCR (2016b), there are a total of 65 million displaced persons worldwide. The portion of these displaced persons (DP) who are children increased from 41 in 2009 to 51 per cent in 2015. A part of the DPs seek asylum in Europe. Many of the children DPs are unaccompanied.

There are a large number of unaccompanied minors who seek asylum in countries around the world, with this number increasing year after year. In 2013, 25,300 unaccompanied minors sought asylum in a total of 77 countries according to UNHCR (2014), in 2014, 34,300 unaccompanied minors sought asylum in a total of 82 countries (UNHCR 2015) and in 2015, 98400 unaccompanied minors sought asylum in 78 countries. There is considerable uncertainty regarding these statistics. The actual number may be significantly higher. There is missing information from some countries as South Africa and the US.

Over a number of years up until 2016, Sweden was the country that received the most asylum applications from unaccompanied minors in Europe (Eurostat, 2015, 2016; Swedish Migration Agency, 2015). In the table 1, we present details about the EU countries that received the most asylum seeking minors over the past decade.

We also present the equivalent figures for the other two Nordic EU member countries, Denmark and Finland, and also one of the two Nordic countries not being members of the EU, Norway. We have not included Iceland. In two years (2012 and 2015), five unaccompanied minors seeking asylum arrived in Iceland, in other years there were none.

\footnotetext{
${ }^{1}$ See Hjeds, Löfmark and Eriksson (2016), for a map of human trafficking in the EU. Of the cases discovered, 13 per cent concern girls and 3 per cent boys. Other cases concern adults - in the majority of cases, women.
} 
In 2015, 35,369 unaccompanied minors seeking asylum were received in Sweden, with the majority coming from Afghanistan (Swedish Migration Agency, 2016). ${ }^{2}$ In 2015, Germany received the second most asylum applications from unaccompanied minors in Europe.

Table 1. Unaccompanied minors seeking asylum in certain EU countries, EU total and Norway $^{3}$

\begin{tabular}{|l|l|l|l|l|l|}
\hline \multirow{2}{*}{ Country } & \multicolumn{5}{|c|}{ Year } \\
\cline { 2 - 6 } & 2008 & 2010 & 2012 & 2014 & 2015 \\
\hline Sweden & 1,510 & 2,395 & 3,580 & 7,050 & 35,250 \\
\hline Germany & 765 & 1,950 & 2,095 & 4,400 & 14,440 \\
\hline Austria & 695 & 600 & 1,375 & 1,975 & 8,275 \\
\hline United Kingdom & 4,285 & 1,715 & 1,125 & 1,860 & 3,045 \\
\hline The Netherlands & 725 & 700 & 380 & 960 & 3,855 \\
\hline Italy & 575 & 305 & 970 & 2,505 & 4,070 \\
\hline Denmark & 300 & 410 & 355 & 820 & 2,125 \\
\hline Finland & 705 & 330 & 165 & 195 & 2,535 \\
\hline All 28 EU countries & 11,700 & 10,620 & 12,545 & 23,075 & 88,265 \\
\hline Norway & 1,045 & 220 & 495 & 780 & 5,050 \\
\hline Source: Eurastat & 3 up & $31 / 07 / 2015)$ & $2 n U(2016 b)$. & &
\end{tabular}

Source: Eurostat (update 31/07/2015) and EU (2016b).

UN Convention on the Rights of the Child (1989), ratified by all EU countries, is to be implemented by using "The principle of best interests of the child" as an overarching principle and guidelines. These principles are expected to influence law-making, administrative decisions and all other actions affecting the children. Unaccompanied minors are seen as a group that particularly needs protection within the context of these guidelines and that needs of this group is to be prioritised. However, there are only a few child-specific provisions in place with regard to the conditions of unaccompanied minors with regard to entry and integration. Furthermore, there are only a few specific provisions in the legislation for UAMs who arrive in the Union without applying for international protection (EMN, 2015).

To be able to evaluate the policies in this area and to be able to monitor the rights, conditions and challenges for this group, it is important to have good register data and that the statistics from these data are readily available. High quality data specifically on different groups is crucial for visibility, being able to take care of children's rights and wellbeing. Best interests

\footnotetext{
${ }^{2}$ In 2016 much fewer unaccompanied minors have applied for asylum in Sweden; only 1584 in January-July 2016 (Swedish Migration Authority 2106-08-01.

${ }^{3}$ Note that there are some differences between the numbers reported in country reports and those in the Eurostat/EU-reports.
} 
determination (BID) describes the formal process designed to determine the child's best interests for particularly important decisions affecting the child. Chapter 2 in BID emphasizes the importance of monitoring the effectiveness of past measures and addressing the gaps identified (UNHCR, 2008). Clearly, one of the ways of achieving this goal is through analyses of comprehensive longitudinal data including the whole population of this group. Detailed data related to this group make it possible to follow the group's development and also provides a basis for evaluating different actions aimed at this group. Many investigations highlight the importance of quantitative studies of comprehensive data material for this group as an important complement to qualitative analyses (McDonald, 1995; Refugee Council, 1999; Andersson-Brynja and Melchert, 2010; Ekenberg, 2011).

Not all children seeking asylum have their application approved. However, the quality and availability of statistics for the number of applications granted varies greatly between different EU member countries. There is a lack of information for the majority of EU countries, only some countries have details about the portion of unaccompanied minors being granted asylum out of those who have their cases determined during the course of a year. Here, we provide the numbers for the countries included in the table above and for which there are also details about the share of minors who received a positive decision during 2013. See European Migration Network (2015b; calculations based upon details presented in Table A1.3). In 2013, the number of unaccompanied minors who had their applications granted was 66 per cent in Sweden ${ }^{4}, 81$ per cent in the United Kingdom, 54 per cent in the Netherlands, 52 per cent in Italy ${ }^{5}, 80$ per cent in Finland and 77 per cent in Norway. Those who received a decision in 2013 may have arrived during said year but also in the preceding years. In many cases, the asylum process takes a very long time. Even though the portion of those seeking asylum and who are granted asylum is not the highest in Sweden, the total who have received asylum has been higher in Sweden than in any other European countries for several years.

The total to receive a residence permit varies greatly depending on the country from which the child has come. ESPON (2015) presents the number to have received positive and negative decisions respectively for the period of 2010-2015 (3rd quarter) for the eight countries that received the most asylum seekers from the top eight countries where the asylum seekers originated. This information applies to all refugees, not just unaccompanied minors. However, it is roughly the same for unaccompanied refugee minors. The portion to receive a positive or

\footnotetext{
${ }^{4}$ In Sweden, the portion was the same in 2015 - 66 per cent - but it was 75 per cent in 2014. See the Swedish Migration Agency (2016).

${ }^{5}$ In 2013 , there were only a few asylum cases decided in Italy.
} 
very positive decision (temporary or permanent residency) is very high or high for those from Syria (92\% yes), Eritrea (85\%), Somalia (65\%), Iraq (64\%) and Afghanistan (61\%), whereas it is low for those from Russia (17\%), Kosovo (5\%) and Serbia (2\%) - i.e. countries in Europe.

There are various reasons for being granted asylum and consequently a residence permit: 1) refugee in accordance with the UN Refugee Convention, 2) otherwise in need of protection and 3) special distressing circumstances. The composition behind the reasons for the decision can vary from country to country and from year to year; for example there can be differences to the types of residence permit and the possibility to be reunited with family members.

Although the unaccompanied minors are 'vulnerable' in different parts of the migration process, several studies have stressed the strength, resilience, and agency of unaccompanied minors, despite the traumatic experiences and challenges (Luster et al. 2010; Derluyn et al. 2008). The victimization of refugee groups in general and the Western trauma discourse is criticized, where certain methods and programmes are imposed on these groups (Summerfield, 1999). Both integration and the well-being of this group can be achieved by identification of the specific needs and challenges for this group at the different stages of their lives and planning policies in line with these needs. The methods and the degree to which this is done vary across countries and is not necessarily done in a systematic way. Thus, the goal of this study is to review the literature in different countries in relation to the issue of unaccompanied minors in the major fields of reception, housing, education, employment and health to see which issues are highlighted and to learn from the experiences in different countries. Clearly, the global movement of separated children is a global concern and the protection of these children is possible only through international cooperation with the major concern for the best interest of the child.

The aim of our study is to see what has been recorded in literature addressing the various central areas concerning unaccompanied minors - such as reception, accommodation, work and health - and through this, draw on the experiences of different countries. Unaccompanied minors and their conditions are an international matter and therefore it is very important for global collaborative efforts to find ways to help the unaccompanied minors. Our survey is on the circumstances surrounding the unaccompanied minors and how various measures can influence and improve their conditions. 


\section{Experiences from Sweden}

The first area of our overview looks at Sweden's recent experiences as far as these have been documented in research and reports. ${ }^{6}$ Many efforts are being made at different levels to be able to receive the unaccompanied refugee minors. In addition, a number of reports have also been compiled by the affected authorities at central, regional and local levels. Other material is also available from unions and other organisations, in addition to research in different areas. Here we provide a structured run-through of the material and use this to draw conclusions about what can be learnt from these efforts and what can be applied by other actors. This applies to the measures implemented directly after their arrival in Sweden and also where they are housed, their education, work and health. There is also reason to pay attention to whether these experiences and future efforts can be evaluated in a more structured manner. Here we have presented a number of results from these studies. Further details can be found in the reports and articles to which we refer.

\subsection{The introductory stage ${ }^{7}$}

In Sweden, the Migration Agency is responsible for the introductory stage. After being placed in an arrival municipality (in arrival accommodation), the child is then placed in accommodation in an assigned municipality. This is to take place quickly, but often takes time.

Since the official international and national definition of an unaccompanied minor refers to the age at arrival at the border of the final destination country rather than the migration process itself; first, it needs to be established that the child is less than 18 years of age contemporaneously. An initial assessment is conducted directly upon arrival, to refer any clear cases of persons over the age of 18 to seek asylum as an adult. At a later stage, a more in-depth assessment, such as an interview, is conducted in the event that there is uncertainty of the applicant's age.

\footnotetext{
${ }^{6}$ Unaccompanied refugee minors have been coming to Sweden for a long time. The most discussed previous experience is that of the Finnish children who arrived during the Second World War. See, e.g. Paksuniemi (2015) for a study of their experiences from interviews and Santavirta et al. (2015) for a study examining the long-term health effects.

${ }^{7}$ A thorough presentation of the different phases has been provided by the Swedish National Board of Health and Welfare (2013). Practical advice has been provided by the Swedish National Board of Health and Welfare (2013a) and Kommunförbundet Stockholms Län (2013).
} 
There is comprehensive research regarding the use of teeth and skeleton X-rays to establish the child's age; see Olze et al. (2006) and Schmeling et al. (2006) for surveys, and Hjern and Ascher (2015) for a contribution to the current Swedish debate. ${ }^{8}$ Their overall conclusion is that there is considerable uncertainty about the estimations that can be made using these methods. The Swedish National Board for Health and Welfare (Socialstyrelsen) has made surveys of various methods to establish the age of the children and also proposed a method that should be used; see Socialstyrelsen (2016a, 2016b).

The second stage includes investigating the child's family circumstances. Is it possible to establish a reunion with the family in their home country or, if this is not possible, in another country?

The third stage is to investigate whether the child has substantial cause to be granted asylum i.e., they have fled from circumstances that entitle them asylum, but also that an assessment in accordance with the Dublin Regulation should not be conducted in another EU country. The Dublin Regulation (EU no. 604/2013) regulates which country is responsible for considering an application for international protection.

Human Rights Watch (2016) has published a report on the situation during and after the large inflow of unaccompanied children in Sweden in 2015, pointing at several problems in the handling of the different parts of the introductory stage during this period.

The Migration Agency decides whether asylum will be granted or not. If the Migration Agency's decision is negative, it is possible to turn to a Migration Court and, as a final resort, the Migration Court of Appeal. Despite some children having their asylum applications rejected, it is not always possible to force the child to leave Sweden. Members of the Union for Professionals, SSR (2015) stated in a survey that this is a large or very large problem. In many cases, it is not possible to deport the child to their home country, as it refuses to receive the child.

Some of the children seeking asylum abscond during different stages of the asylum seeking process. The majority who abscond do so during the transfer phase (arrival accommodation), whilst fewer abscond from the assigned accommodation. Those who abscond from assigned accommodation usually do so after their application for asylum has been rejected. Those from countries for which many applications are rejected - such as Algeria and Morocco $^{9}-$ abscond $^{2}$

\footnotetext{
${ }^{8}$ Also see Hjern et al. (2012) for an analysis of the difficulties in establishing a child's age when no reliable documentation is available.

${ }^{9}$ See Lang and Popadic (2016) for a study of children coming to Sweden from these two countries.
} 
to a much greater extent than those from countries such as Afghanistan and Syria - most of whom are granted asylum. Of those to arrive between 2010 and 2015, 34 per cent from Algeria and 27 per cent from Morocco absconded, in comparison to a mere 1 per cent of those from Afghanistan. See Kullander et al. (2016). Few of those to abscond are found, or can be assured to have returned home or continued to another country. The majority most likely remains in Sweden.

The children receive financial support during the asylum application process. The financial support system changes once a residence permit has been granted just as when the child turns 18. Different areas of responsibility are distributed over several authorities such as the Migration Agency, county administrative boards, county councils, municipalities, the Swedish National Board of Health and Welfare and the Health and Social Care Inspectorate. These authorities have various responsibilities for the child, everything from the asylum process, living conditions, accommodation and education to pocket money. The municipality appoints a custodian and personnel at the child's accommodation to be responsible for ensuring the child's rights are catered for (Swedish Migration Agency 2015). Rights cover the period up until the child turns 21. See Swedish National Board of Health and Welfare (2015) for a breakdown of the various allowances.

\subsection{Accommodation placement}

The first placement is at accommodation in an arrival municipality - accommodation for the period immediately after the child's arrival in Sweden. This accommodation is intended to be temporary, however for many children it becomes long term. See Ombudsman for Children in Sweden (2016) for a study based upon group interviews of approximately 450 unaccompanied minors at different arrival accommodations. The interviews took place between October and December 2015, a period when many children arrived in Sweden. The report concludes with a number of suggestions for improvements to the system. According to the report, the most important suggestion is that actions are taken that in turn reduces the amount of time spent at the arrival accommodation. It is also important that activities are provided for those at the arrival accommodation. Many municipalities have activities aimed at helping the brand new arrivals. One example is the "Landningsbanan" reception centre for newly arrived refugee families in Växjö municipality. The importance of a guardian (god man) at every stage of the process, an adult as the main contact and legal guardian of the child that the child can trust and receive guidance is emphasized in this report. 
Malmsten (2014) presents a study that builds upon interviews with eleven unaccompanied minors at arrival accommodation in Malmö. The children continually say that they are satisfied with the accommodation, which in itself could be attributed to the fact they have lived in worse conditions on their way to Sweden, or, they do not want to appear ungrateful. In the analysis of the interviews, the author emphasises the importance of structure to their stay and the value of organised activities.

The child is then placed in another accommodation in an assigned municipality. The majority of unaccompanied minors are placed in accommodation provided by the Migration Agency (ABO), a part of them in a home for care and accommodation (HVB housing), but some children are placed in a foster home, depending on their age. As a rule, the youngest are placed in foster homes. If they have relatives in Sweden, they can be placed with them. This is known as private accommodation (EBO), and is located in the municipality where their relatives live. See Iveroth (2015). As in the case of other forms of living, there are several institutional, legal and ethical issues regarding the process and aftermath of this type of accommodation, which have potential important consequences for the child's well-being (Backlund, et al., 2012).

Up until 2014, the placement in a municipality was entirely based on agreements between the Migration Agency and various municipalities. As of 2014, the Migration Agency has the authority to place unaccompanied refugee minors in all municipalities, without there being such agreements.

As stated previously, the HVB is an important form of accommodation. In their inspection of HVBs for children and youths during 2014 and 2015, the Swedish Health and Social Care Inspectorate (IVO) saw various forms of unsatisfactory conditions. See IVO (2015).

As of 1 July 2006, the municipalities were allocated an increased role in the reception of unaccompanied minors. Gradually, more municipalities signed reception agreements with the Migration Agency for unaccompanied minors. Lidén and Nyhlén (2015) have studied the municipalities that had reception agreements in each of the years between 2008 and 2011. Over the four years, the municipalities with a high portion of residents with higher levels of education more often received unaccompanied minors, compared to other municipalities. For other variables, the coefficients were not significant all years. This can be explained by the fact that more municipalities began receiving unaccompanied refugee children and consequently, there was less variation to explain. Attention can be brought to some results from the study, such as municipalities with a greater population often received children, and 
municipalities with a higher portion of voters for the centre-right Moderate Party and the farright Sweden Democrats received fewer unaccompanied minors.

The system after its reform in 2006 now means that municipalities have to collaborate in their work with receiving unaccompanied refugee minors. A study by Bloom (2008) shows that initially, there have been problems related to the formation of this collaboration.

A longitudinal study (Stretmo and Melander, 2013) that follows 154 unaccompanied minors who arrived in the Gothenburg region in 2008 found that the children often changed accommodation on at least one occasion. For the children who are placed with relatives, these accommodation changes are less common.

In a qualitative study of a small number of children placed with their relatives, Backlund et al. (2012, pp. 99-103) indicate that being placed in homes with relatives/connections often takes place without thorough investigation and follow ups are often less comprehensive than for children who are placed in other forms of accommodation. They also show how financial support for these homes varies considerably amongst the 22 Stockholm County municipalities included in their study.

The type of accommodation best suited to the different groups of unaccompanied minors is a greatly debated topic. There are various challenges, risks and support systems in relation to the different forms of living (Brendler-Lindqvist, 2004; Wallin and Ahlström, 2006; Wimelius et al., 2016; Iveroth, 2015; Stretmo and Melander, 2013; Fälldin and Strand, 2010).

One of the most important support systems identified in the studies in Sweden in relation to accommodation type is contact with the personnel. Contact with the accommodation personnel is very important and can, to a certain extent, be said to replace the contact with the family members who are not present. Regular, daily contact with the personnel is essential. Contacts with other children living in other accommodations have also been found to be very important. See, e.g. Wimelius et al. (2016), a study on receiving unaccompanied refugee minors in Umeå.

In a survey, members of the Union for Professionals SSR (2015) state that one important matter is finding alternative forms of accommodation than the HVB for the children who do not require special support. Such accommodation has now been introduced. Since 1 January 2016, there has been a new form of accommodation, supported housing, which is to be less invasive in the lives of the children and young people. This is aimed at children and young people aged between 16 and 20. For the legislation governing the new form of 
accommodation, see the Swedish Social Services Act, (SFS 2001:453) and the Swedish Social Services Ordinance, (SFS 2001:973). For a presentation of these, see the Swedish National Board of Health and Welfare, (2016). For criticism of the new supported housing see Ramel and Assel (2015). They argue that the housing support should be more qualified.

\subsection{Guardians, specially appointed custodians and other groups of responsible personnel}

Several studies show the importance of networks in building country specific human capital and for employment outcomes (Sjögren and Zenou, 2007). The way the asylum process, reception and accommodation of this group are organized unaccompanied minors are obliged to be in contact with several key persons from the Swedish society to be able to navigate in the Swedish system. The guardian ('God man') and the personnel at the accommodation are some of these contacts (Iveroth, 2015). These contact are potentially very important for the development and integration of this group (Stretmo and Melander, 2013; Fälldin and Strand, 2010).

The right for children in Sweden to have a legal guardian was established in 1948. In 2005, legislation was passed extending this right to include unaccompanied refugee minors. This legislation regulates the right to get a guardian. Before the child receives a decision of whether they will be granted a residence permit, the municipality's Chief Guardian Committee appoints a guardian who is to act in the child's best interests. The guardian gives power of attorney to a public counsel, who represents the child upon their application for asylum. A special custodian is appointed to a child whose application for asylum has been granted. The appointment of guardian/special custodian ends when the child turns 18 . This means that when they turn 18 , the child loses support that may have been very important to them. When this support ends, support from fellow countrymen becomes very important. See Eriksson et al. (2014) who present experiences from a study of unaccompanied minors in Umeå.

The Chief Guardian Committee has the important task of inspecting the guardian's work. They are tasked with several duties and varying complaints are often made aimed at their work. A report by the Swedish National Audit Office (2009) emphasises that county administrative boards shall be more active with the inspections of the Chief Guardian Committees' activities. The inspection of the quality of services of the guardians has been a widely debated issue in Sweden recently. 
In a survey, members of the Union for Professionals SSR (2015) state that a large or very large problem is that children are, on the one hand, assigned people to whom they have weak or uncertain links, and on the other hand, the guardians whom the children are appointed are often responsible for far too many children.

\subsection{Education}

Education is extremely important for the well-being and integration of refugee children, regardless of whether they are unaccompanied or arrive with their families. It is important that education is adjusted so it is meaningful to the children, provides support during the school days, helps them develop the skills relevant to the society where they arrived and provides skills relevant to working life. Education is also a protective factor for refugee youth. Relevant and responsive education offers stability and purpose, opportunities to rebuild social capital, re-establish a routine and continued essential development of skills and knowledge for future generations (Ackerman et al., 2014). The specific importance of schools is discussed in the case of unaccompanied minors in terms of providing daily routines and a safe environment for their well-being (Bhabha, 2004; Seglem et al., 2014).

Education is central to integration in Sweden. The majority of children arrive in Sweden when they are of upper-secondary school age, or at the age of higher classes of the compulsory school. However, generally speaking they cannot be directly placed into the regular school system. Education in Swedish is commonly the first step of the education. Good knowledge of Swedish is important both for continuing education and for joining the labour market later on. ${ }^{10}$ The situation varies depending on the age of the child when they arrive in Sweden, amongst other things. As a rule, the younger the child, the easier it is for them to learn Swedish. Other forms of introductory processes are available before the child is placed in the regular education system.

If we consider all newly arrived immigrants who are children (unaccompanied minors or otherwise), those aged between 1 and 12 constitute around 2 per cent of all children in preschool and grades 1-6 of compulsory school. However, these children make up around 5 per cent of all children aged 13-15. At this age, the children are in grades $7-9$ of compulsory

\footnotetext{
${ }^{10}$ For adult refugees Swedish for Immigrants (SFI) is very important. The percentage of people who start SFI before their fifth calendar year after their immigration is highest amongst those who arrived in Sweden as refugees. See the Swedish National Agency for Education (2014).
} 
school. Finally, 8 per cent are aged between 16 and 18, i.e., of upper secondary school age. See the Swedish National Agency for Education (2016).

It is also important to pay attention to the child's existing level of education when they arrive in Sweden. Such information is important to be able to place the child at the right level in the Swedish education system.

A follow up study of unaccompanied minors in the Gothenburg region who arrived in 2008 (Stretmo and Melander, 2013), shows that the children were placed in the compulsory school or upper-secondary education, but few of them were placed on the regular programmes. Instead they were placed in special preparatory classes. One advantage of such teaching is that it is better tailored to what the children can accomplish; however, at the same time there is the disadvantage that they will not be integrated with other children to the same extent.

School provides contacts with friends, teachers and other personnel. It is important that the teaching of unaccompanied minors does not take place in isolation from other pupils. Instead, teaching should take place with the other pupils so the unaccompanied minors can more easily integrate into society. At the same time, it is important that they have contact with pupils in similar situations. See Wimelius et al. (2016) for a study of unaccompanied refugee minors in Umeå.

One interesting, yet small-scale activity that is yet to be evaluated is "Folkhögskolespåret" the Folk High School Track. Two advantages can be the relatively low costs and integration with children other than refugees. See Folkhögskolespåret [Folk High School Track] Swedish National Agency for Education (2016).

\subsection{Work}

After a short or longer period of education, the next stage is becoming established on the labour market. According to studies on Sweden, employment rates for unaccompanied minors vary across gender, country of origin, education as well as where the children are placed. Female unaccompanied minors establish themselves on the labour market to a lesser extent than boys, where time spent in Sweden is an important factor that influence employment rates positively. The strength of the labour market differs in different areas of the country, affecting the child's possibility to find work. 
For a more detailed discussion in this area we can refer to our own work. See our reports including Çelikaksoy and Wadensjö (2015a, b, c, and d) and some of our articles. See Çelikaksoy and Wadensjö (2015e, 2015f and 2016).

For an early study concentrating on a group of 100 unaccompanied refugee minors, see Hessle (2009). The results presented in this study indicate that the children establish themselves on the labour market after a number of years in Sweden.

\subsection{Health}

The migration process for children having to migrate alone is an extremely strenuous experience. The children who arrive have considerable strength. In this respect, they are a positively selected group. On the other hand, the children have generally had traumatizing and difficult experiences in their home country (which led to their escape), as well as during their struggles to reach the destination country. There is also another factor that can affect the health of the child. For many, changing environments is difficult. Sweden is, in many ways, considerably different to the countries the children have left and the demands for adaptation and integration can be extensive. They may also be met with discrimination and hate. See Hirvonen (2013) for a study of negative attitudes and actions directed towards unaccompanied refugee minors in Vallentuna (a municipality in Stockholm County).

Other sources of difficulty for the unaccompanied minors can include the uncertainty and psychological challenges during the period until the decision is made for whether the child can remain in Sweden or not. For those children who have their asylum application refused and consequently do not receive a residence permit, the uncertainty of what is ahead is augmented. Furthermore, lack of clear information at each step of the asylum process as well as afterwards contribute to the uncertainty and psychological challenges. Clear information informed in an age, ethnically and educationally appropriate way to the children regarding their rights, options, possibilities at each step of the way would significantly contribute to the well-being of children.

Ramel et al. (2015) examined the rate of hospital in-patient admissions (voluntary and compulsory) for psychiatric care amongst unaccompanied minors compared with other children in Skåne. The results showed that the admittance rate for unaccompanied minors is considerably higher. The majority of the unaccompanied minors admitted are still going 
through the asylum process or have had their application rejected - i.e., they do not have a residence permit in Sweden and as a result they are in a very uncertain position.

\subsection{What is it like when the children become older?}

Unaccompanied refugee children have been arriving to Sweden since the 1990s. However in comparison to the number of children to arrive later on, they were relatively few. It is vital to follow the children until they become adults to be able to answer certain important questions about their integration in Sweden. What will their highest level of education be as they approach their thirties? How will they be able to establish themselves on the labour market in the short and long term? Will they remain in Sweden or will they return to their home countries if the situation improves there? These are some important questions to look at also in future research.

\section{Studies on the experiences in other countries ${ }^{11}$}

The second area for our overview includes studies of the experiences of other countries documented in research. Even though Sweden has received the most unaccompanied refugee children in Europe, other countries within Europe and beyond have received many unaccompanied refugee minors. As a result, they have experience of what happens to the unaccompanied refugee minors, in addition to research that evaluates and assesses different measures. This applies for Finland, Norway and the United Kingdom for example, but research, enquiries and debate from other countries are also available. We provide an overview and discuss the results. We group the results in two ways - after country of reception and the various stages of the events. This in part leads to an overlap, but we think that there are advantages to such a division. In the case of the country of reception, we will also pay attention to the unaccompanied minors who arrive for reasons other than seeking asylum. Many unaccompanied minors arrive in countries such as Italy, the USA and other ACP states ${ }^{12}$ but do not seek asylum. Their main aim is to make a living through working or in other ways. These children are often in very difficult situations.

When we compare different countries, we must remember that the composition of the unaccompanied refugee minors differs for many reasons from country to country, hence so do

\footnotetext{
${ }^{11}$ See Watters (2008) for a social anthropology-based overview.

${ }^{12}$ ACP states include countries in Africa, the Caribbean and Pacific.
} 
the grounds for permits. Additionally, regulations and assessments vary between the countries.

As stated, we will begin by discussing the experiences in different countries individually, and then look at the collected experiences at the different stages of the decision process, followed by the integration of the unaccompanied minors in the receiving societies. With a few exceptions, the research that is referred to is based on small scale studies, which involve interviews of a small number of unaccompanied minors, or on analyses of children who have been in contact with health care services. Sweden and Norway are almost unique in having an individual-based high quality data register that includes all children that have been entered into the population register, with details about those who arrived as unaccompanied minors. On the other hand, the analysis of interviews ${ }^{13}$ and surveys can map other circumstances that cannot be examined with the help of the registered data. Quantitative register-based surveys and qualitative analyses complement each other. We can learn a lot from qualitative surveys.

\section{The neighbouring Nordic countries}

For a number of years, the total of asylum applications made in Sweden from unaccompanied refugee minors has been decidedly higher than in the other Nordic countries. This has not always been the case. As late as 2009, the total was roughly the same in Norway and Sweden. During 2014, the total of applications was much higher in Sweden than in the other three countries (here we have examined and compared the experiences in Denmark, Finland and Norway). Within the Nordic countries, after Sweden, the majority of unaccompanied minors sought asylum in Norway and Denmark, whilst markedly fewer sought asylum in Finland. In 2015, the number of asylum-seeking unaccompanied minors increased in all four countries, also in Finland. The differences between the countries may be as a result of differences in regulations, but also as a result of the existence of networks.

The conditions for unaccompanied minors seeking asylum differ between the four countries. ${ }^{14}$ For example in Finland, permanent residency has as in Sweden generally been granted, however temporary residency has been given to the children who receive permits on humanitarian grounds. In Denmark, a residence permit is typically granted for up to four years

\footnotetext{
${ }^{13}$ However there are ethical problems with interview studies. They can give the interviewee hope of help that the interviewer cannot offer. See Vervliet et al. (2015) for a discussion of the ethical problems.

${ }^{14}$ We base our summary on the regulations that applied up until the autumn of 2015 and not on the changes implemented in the latter part of that year or in Sweden from July 20, 2016 or in the other Nordic countries.
} 
(up until the maximum age of 18) with the possibility for it to be extended until they turn 18 . Before turning 18, the child needs to submit an application for a residence permit in good time to be valid from this age and therefore as an adult asylum seeker. Otherwise, the child must leave Denmark once they reach 18. It is the same in Norway; for a number of children who arrived between the ages of 16 and 18, the residence permit expires when they turn 18 .

In Denmark, the child is first placed in a centre for asylum seekers. If and when the permit has been granted, the responsibility is transferred to a municipality that will then organise accommodation for the child. There are various types of this accommodation. In Norway, accommodation is different for children under the age of 15 and for those between 15 and 18 . As a rule, placement has three stages, slowly aiming towards more independent accommodation. In Finland, the child is first placed in an asylum centre, whilst in the cases where asylum has been granted, the child is generally placed in a group care home. Subsidised housing may be an option for children aged 16 or older.

It has been relatively easy to reunite unaccompanied refugee minors in Sweden with their families, but this has gradually become more difficult or impossible in the other three Nordic countries. Of the applications to reunite families made in Finland during 2013, only one application was granted whereas 156 were refused. See Björklund (2015). Sweden has now moved towards legislation similar to that in Finland.

\subsection{Denmark}

One study (Christensen, 2006) discusses the conditions for unaccompanied refugee minors in 2006 at the sole accommodation centre in Denmark for this group of children in that year Center Gribskov run by the Danish Red Cross. At the time of the study, the centre housed 26 children. However a total of approximately 100 children had been placed there at some point during the year, either for short or long periods. A number of children had left, either after having been classified as adults and subsequently being moved to accommodation for adult asylum seekers, or by absconding. Three quarters of the children were boys, with the majority being 15,16 or 17 years old. They had come from several countries, but the most common were Afghanistan and Iraq. The majority of the children who remained and completed their applications were refused that year. There were three types of accommodation at the centre: reception accommodation, a home for children and youths, and a smaller accommodation for a maximum of four youths. According to the author of the report, the accommodation 
standards were high. The children were taught Danish and went to school where the majority of lessons were in Danish. Extra-curricular sports activities with Danish youths were available.

Save the Children Denmark (2010) deals with a slightly later period in Denmark, when the total of unaccompanied minors had become significantly higher. The study includes unaccompanied refugee minors that had been placed in accommodation in five different municipalities. It primarily builds upon a total of 36 interviews of personnel and unaccompanied minors. The majority of the children had come from Afghanistan. Generally, the children were positive about what they had been offered, but some of the personnel interviewed directed criticism towards deficits in the reception. The interviews - and subsequently the criticism - deal to a great extent with the accommodation and the teaching. Another area of criticism was that the rule stating that each child must have a special representative had not been put into practice.

\subsection{Finland}

In 2008, the total of unaccompanied asylum-seeking children in Finland reached its peak with 706 applications, compared to previous years with fewer than 100 applications per year. See EMN (2014). The number gradually declined and has settled at a level of between 100 and 200 applications per year. 2014 saw a total of 196 applications. Of the applicants in 2014, 84 per cent were boys. The largest number came from Somalia (48) and Afghanistan (47). For 2014 in total, a decision was made for 78 asylum applications for unaccompanied minors in Finland (see EMN, 2015b). Of these decisions, 64 were positive. The most common reason for a positive decision for asylum was subsidiary protection.

In 2015, certain legislative changes in Finland were made. Greater demands were placed on the migration authority to attempt to establish contact with the child's parents and in doing so, hoping that the child more often could be returned to the home country. The rules were also changed so that the placement of children under 15 in custody whilst waiting for deportation was forbidden. See EMN (2016).

In 2015, the number of unaccompanied minors seeking asylum increased substantially. It reached 3024 minors seeking asylum according to the Finnish Immigration Service (2016). However, only 168 applications were fully processed in 2015 of which 112 had their application granted. 
Björklund (2015) conducted an interview-based study of 13 people living in Turku that had arrived in Finland as unaccompanied minors - ten men and three women. At the time of the interviews, the majority was in their early twenties, whereas two were in their forties; they had all been in Finland for a number of years. Eight who had worked with unaccompanied refugee minors, either as social workers or administrative personnel, were also interviewed. Here we will draw attention to some of the results and the conclusions reached by the author. One result is that children are incredibly worried about the situation their family members are in back in their home country or elsewhere. The children feel responsibility towards their family members (and try to help, mainly by sending money). Another result is that the unaccompanied minors find it difficult to make Finnish friends - those to have made such friends were mainly some of the boys who had Finnish girlfriends. Emphasis was placed on how they had great trouble learning Finnish and as a result, found difficulties assimilating into education and eventually finding a job. Another thing emphasised in the interviews were the difficulties faced after turning 18 when different types of support were withdrawn or reduced. Another problem that was mentioned was how the asylum centres and group foster homes were placed in different parts of the country. It was therefore difficult for the children to keep in contact with the friends they had made at the asylum centre upon arriving in Finland once they had been moved to a group foster home. EMN (2014) also emphasise the importance of avoiding re-housing and how being placed directly into a group foster home should be the aim.

\subsection{Norway}

Norway received a peak of unaccompanied asylum seeking children in 2009. At that time, the number seeking asylum was roughly the same size as in Sweden. However in the years after 2009, the number of unaccompanied minors dropped. Explanations contributing to this might be that the Norwegian authorities clearly expressed that they would start following the Dublin Convention and that the residence permits granted to children on humanitarian grounds would only be temporary and expire when the children turned 18. See Stabell Wiggen (2014). But as in most other European countries the number of the asylum seeking minors increased very much in 2015.

Like Sweden, Norway has a good comprehensive register from which it is possible to follow children who arrived as unaccompanied refugees over the years. In one study (Stabell 
Wiggen, 2014), the refugee children who arrived in the period from 1996 until the end of 2011 were followed (resident in Norway 01/01/2012). ${ }^{15}$ The children followed were those to be granted permission to stay and who had not left Norway or died. There were 4,783 people in total. The majority of the children came from Afghanistan. Other countries of origin included Somalia, Iraq, Sri Lanka, Ethiopia and Eritrea. With the exception of Sri Lanka, these are the same countries from where many of the children came to Sweden.

Approximately 80 per cent of the children included in the study were men. The number of men dominates amongst those who are from Afghanistan and Iraq, whereas the gender distribution amongst those to come from African countries is almost even. More surprisingly perhaps was that over half were aged 16 or younger. A large number of the unaccompanied minors live in the Oslo municipality, considerably more than the number to originally be placed there. In other words, many of the children have moved to Oslo. Other larger cities have also received additional net contributions. Half moved from their original municipality of residence during the period of the study. The migration pattern is reminiscent of Sweden.

The study pays particular attention to the activities of those who arrived as unaccompanied refugee children and who, in 2011 were aged between 18 and 29. Comparisons are then made to other groups of the same age. They find that more than two thirds ( 71 per cent) of those who arrived as unaccompanied minors are in work and/or studying. This is lower than for the total population of the same age. Unemployment is higher amongst the unaccompanied minors and many receive different forms of income transfers. Women are more often in education than men and are at home with the children considerably more often. The rates of employment are significantly higher amongst those who have been in Norway for a longer period of time than those who have only been there for a short while. There are substantial differences amongst the number of employed between those from different countries. People from Sri Lanka have the highest employment rates, approximately the same as for the entire population. Employment rates are significantly higher for those living in Oslo, compared to those living in other municipalities. ${ }^{16}$ There is a clear over-representation of those in employment who arrived as unaccompanied minors in the catering industry, compared to the rest of the Norwegian population of the same age. When compared to the rest of the

\footnotetext{
${ }^{15}$ See Aalandslid and Walstad Enes (2012) for an earlier study. A brief follow-up study that covers an additional two years is available, see Stabell Wiggen (2016). For the areas where the results are presented in the most recent, shorter report, the results are fundamentally the same as those presented in Stabell Wiggen (2014). ${ }^{16}$ One shortcoming of the study is that the variables are treated one-by-one and so no consideration is taken to the covariance between different explanatory variables. A higher portion of those from Sri Lanka live in Oslo than is the case for those from other countries. Is this high level of employment amongst those from Sri Lanka partly or entirely due to the fact that they live in Oslo?
} 
population of the same age, the unaccompanied minors' incomes are low, with a larger part of the income coming from income transfers. However this number decreases with the number of years spent living in Norway. There are large differences based on the country of birth. Work-based income is relatively high for those from Sri Lanka and relatively low for those who come from Eritrea and Somalia. See also Dalgard (2016), who reports positive results regarding the integration of minors from Afghanistan.

In another study based on Norwegian registry data, Haugen and Dyrhaug (2014) present the child welfare measures taken in 2011 (and with a comparison 2007) for unaccompanied refugee minors who were granted residence permits. The majority was covered by arrangements for accommodation placements and help with their housing, but many also received other types of help, such as financial support and help with activities in their free time.

A Norwegian questionnaire-based study (Oppedal and Idsoe, 2015) included a total of 948 people who arrived as unaccompanied minors. Those who responded to the questionnaire were on average aged 18.6 at the time of the study and had lived in Norway for an average of 3.5 years. They completed a questionnaire about psychological well-being (post-traumatic stress and symptoms of depression) and the types of support they had received in Norway (from their family, Norwegian friends and friends with the same ethnic background), their cultural competence (in their home country and Norway) and if they had felt discriminated against. It was not surprising to see that ethnic competence as well as cultural competence about the host country led to a lower frequency of symptoms of depression, whilst discrimination and post-traumatic stress co-varied with a higher frequency of symptoms of depression. The results highlight the importance of the unaccompanied minors being given a social context, both with those who belong to the same ethnic group and those who belong to the majority group in the new country, as well as combating discrimination.

Another Norwegian study (Svendsen et al., 2008) examined how the housing issue was managed in two Norwegian municipalities - one municipality with a large population, Trondheim and another municipality with a smaller population, Levanger. The study interviewed civil servants within the municipalities and 25 unaccompanied refugee minors. The way the children's accommodation was organised was markedly different in the two municipalities. In the smaller municipality, one authority takes care of all aspects of the refugee children's integration. In the larger municipality, the tasks are divided so just one authority is responsible for housing, whilst other authorities are responsible for other parts of 
the integration. There is a temporal (and age-based) course to the accommodation placement. The housing career begins in institutional housing and then progresses to an "utslussningslägenhet" - a form of accommodation where the youths are able to "practise" day-to-day tasks and develop independence, but still have groups and resources to turn to. Eventually, progression is made to a private apartment combined with follow-ups. The authors stress that the unaccompanied minors have often had a period of independence when they arrive in Norway, but after they have arrived, they receive a period of dependence. It is important to combine independence and support. Here, accommodation plays an important role.

\section{European countries outside of the Nordic region}

Sweden is as mentioned the country to have taken in the most unaccompanied refugee minors in Europe over a number of years. Nevertheless, there are other countries that have received or receive - a substantial number of children seeking asylum. We will in this section discuss the experiences of some European countries other than the Nordic countries.

\subsection{United Kingdom}

If we go back less than a decade, the United Kingdom was the country that took in the most unaccompanied refugee minors in Europe. ${ }^{17}$ This is no longer the case. For a number of years now, the United Kingdom has had a restrictive refugee policy. Furthermore, the exiting of the UK from the EU will also have consequences for this group.

Wilding and Dembour (2015) build their study upon interviews with eleven people who arrived as unaccompanied refugee minors (all of them boys) and 17 people (with different expertise) who have worked with unaccompanied refugee minors in England ${ }^{18}$. They see a number of problems and focus on a few of them. The first problem is that the asylum process takes a long time and is often conducted in a manner that does not show much respect to the child. The second problem is the concentration of the children into a limited number of administrative areas. There are 150 of such areas in England, with seven of them taking in 43 per cent of the children. These areas often do not have enough personnel to be able to cope

\footnotetext{
${ }^{17}$ If we go back to 2000 and 2001, the Netherlands was the country that took in the most unaccompanied refugee minors in Europe. See Ryan (2014).

${ }^{18}$ The study refers to England. Policy differs between England, Northern Ireland, Scotland and Wales - the four regions of the United Kingdom.
} 
with the work in a satisfactory way. The third point of criticism is that there is no equivalent to the Swedish guardianship and appointed custodian system and therefore they suggest that the conditions for such a system be investigated.

\subsection{Germany}

After Sweden, Germany is the country to have received the greatest number of asylum applications from unaccompanied minors in Europe in the years leading up to 2016. It is therefore easy to draw comparisons with Sweden. However, compared to Sweden, Germany does not register the same type of details that make it possible to follow the children over a long period of time. Nevertheless there are a number of different kinds of studies and types of registered information about the children that relate to the period in which they are seeking asylum. The initial stage and a very important stage is the identification of unaccompanied minors as such by the border authorities since underage migrants without parents are subject to particular regulations. This step is a very important step in each country. In Germany, once identified, they will typically be handed over to a Youth Welfare Office, which has to take the minor into care, appoint a legal guardian and arrange accommodation. Afterwards that the process starts, where the individual needs are identified, such as locating the relatives of the child, assessing whether application for asylum is a reasonable way forward, where this procedure is applied differently across the 16 German Federal States with regards to length and quality (Parusel, 2009).

A survey of the development until 2014, Müller (2014), shows that an increasing number of unaccompanied refugee minors has sought asylum in Germany. Most of all, there has been an increase in the number of children arriving aged 16 or 17 . The majority of the unaccompanied minors are boys. This applies in particular to the older children. The majority of children come from Afghanistan, however a considerable number come from Somalia, Iraq, Syria and Eritrea. Approximately only half receive permission to stay. Girls are allowed to stay more often than boys. The number who may remain is high for those from Syria, Eritrea, Afghanistan and Somalia. However, it is very low for those from countries such as Egypt, Russia and Serbia. Up until 2011, the number from Syria to be granted permission to stay was very low. It then became very high after the start of the Syrian civil war. The children who apply for asylum may study, but only those who have received permission to stay may be gainfully employed. However, there is another new law in place which allows unaccompanied minors to stay on after leaving care if they are still under education, vocational training, etc. 
In addition, if they have successfully entered the labour market they can receive a permit to stay even though they are not recognised as refugees.

Germany has 16 federal states, with various policy formations for unaccompanied refugee minors. Until November, 2015 the unaccompanied minors were handed over to the Youth and Welfare Office of the municipality in which they have arrived. This led to huge regional distinctions. Since November, 2015 the unaccompanied minors are distributed within all 641 municipalities in Germany equally (part of the clearing process starts already at the Youth and Welfare Office where they arrive). The distribution is a huge challenge to all the Youth and Welfare Offices that have never dealt with unaccompanied minors. The very important question still remains whether this procedure is in the best interest of the child although it is in the best interest of the municipalities to distribute the costs. In general, each state distributes the children who arrive amongst the state municipalities. The municipalities are to provide care, accommodation, language tuition and schooling, as well as appoint a legal representative for the child. The municipalities have one unit that ensures that all of this is done. All children have the right to attend school, regardless of whether they are asylum seekers or have received a residence permit. However, there are certain differences for both the groups of children regarding the right to vocational education outside of school - the asylum seekers do not have the right to participate in such education (apprenticeship based). It can be difficult to participate in the apprenticeship based education, even for the children who have residence permits due to lack of knowledge of the German language. See Niemeyer (2015).

\subsection{Other European countries}

Many other countries in Europe have received asylum applications from unaccompanied minors and have granted some of them with permits to stay. Here we will briefly touch upon experiences from some of these countries.

Austria is one of the countries in Europe to receive the most asylum seeking children. As in other western European countries, the largest group of unaccompanied minors comes from Afghanistan and mainly consists of boys aged between 14 and 17. See Kopparberg (2014). As in other countries, Austria has rules for establishing the children's ages. In 2013, 15.8 per cent of them were judged to be at least 18 years old and therefore not children in the eyes of the law. 
It is difficult to judge the situation for the unaccompanied minors who receive asylum in Austria, as the responsibility is divided between different authorities on central and local levels and there is no comprehensive statistics system. One problem highlighted is that many children abscond from the accommodation where they have been placed whilst the investigations are taking place to see if they will be granted asylum. It is most likely that they leave Austria to go to another country in Western Europe, a country where they have relatives or friends.

Italy receives quite a number of unaccompanied refugee minors and the number has increased over recent years. Many arrive from nearby countries such as Albania and Kosovo, but many also come from the same countries as the children who arrive in other countries in Western Europe. However, many unaccompanied minors came to Italy and do not seek asylum. These children are often referred to as "undocumented immigrants". It is not the case that they lack "documentation", rather they do not have the necessary documents to have permission to stay in the country. There is a lack of statistics in this area, but those that are available indicate that there are considerably more children belonging to this group in Italy than in other European countries.

A study by Andersson and Petrov (2015) looking at the reception of unaccompanied minors in a reception centre in Genoa points in particular to the importance of the work from social workers - the unaccompanied minors view them as a part of their family. The study builds upon interviews with some of the social workers and unaccompanied minors. The interviews indicate that the lack of special processes for these children within the school system has both disadvantages (language difficulties in school) and advantages (more contact with Italian children).

Unaccompanied asylum seeking children also arrive in central and eastern Europe and in countries included in the EU Eastern Partnership. With the exception of Hungary, where are few or very few. See International Organization for Migration (IOM) (2015). There is a difference in composition in terms of where unaccompanied minors originate from compared to Western Europe, in that relatively many children come from Vietnam. It must however be emphasised that this number is low. 


\section{Countries outside of Europe}

Many countries outside of Europe have received - and receive - unaccompanied minors. We will discuss some of these countries in more detail and then briefly summarise the experiences from some other countries.

\subsection{Turkey}

Since 2009, there has been a dramatic increase in the number of refugees seeking asylum in Turkey. In 2012, the majority of applications came from refugees from Iraq, Iran, Somalia and Afghanistan (FRR 2012; UNHCR, 2012). Even since 2007 the number of unaccompanied refugee minors has increased. The group is composed of mainly irregular migrants. The unaccompanied minors arrive predominantly without documentation that can confirm their identity (Atasu Topcuolu, 2012). To an extent, Turkey is a transit country for unaccompanied minors on their way to other places in Europe, however others seek asylum in Turkey. Unaccompanied minors are one of the groups to be classified as "persons with specific needs", for whom the Ministry of Family and Social Policies is responsible. The Ministry is tasked with placing these individuals in centres for children, women's refuges or other suitable places. If a person is identified and registered as having "specific needs", the person has access to extra protective measures and they have prioritised access to different services such as psycho-social help, rehabilitation and other support. Turkey has joined the Convention on the Rights of the Child, and there are domestic protection norms for children which are generally in accordance with international undertakings.

Unaccompanied minors primarily arrive from regions where there is on-going armed conflict, considerable unrest or risk of famine. To a lesser extent, they come from other neighbouring states such as Bulgaria and Chechnya, from where Turkey has previously received refugees or from countries from which immigration takes place - Georgia and Azerbaijan. A small qualitative study suggests that the main reasons for the migration of unaccompanied minors are political opposition and violence. Survival and being able to live normal lives are two of the children's most important incentives for fleeing. Their destination country of choice often depends on networks with previous migrants in their family, the child's and the family's financial resources and the smugglers' possibilities and networks. The majority of the unaccompanied minors are smuggled into the country (Atasu Topcuoglu, 2012). 
Since conflict began in March 2011, the number of refugees from Syria to arrive in Turkey has increased considerably. There are now 3.1 million Syrian refugees in Turkey, making Turkey the host country with the largest refugee population in the world. More than half of these refugees are under 18 (UNHCR, 2016a). This figure applies to those who registered when they arrived in the country. There are many important issues dealing with the vulnerability of child refugees, regardless of whether they are unaccompanied or followed their parents (Erden and Gurdil, 2009; Özpolat-Olgun and Yuksel, 2001). Nevertheless, the situation for unaccompanied minors is even more difficult and requires special attention.

In Turkey, primary education is compulsory for all children regardless of their legal status and consists of primary and secondary school. Almost all children of school age in the 25 Turkish refugee camps attend school, but only a very small portion of refugee children living in the cities do. It is difficult for the authorities to locate the children that do not go to school in the cities where indeed many of the refugees live. The challenges in relation to education of those living outside the camps have started to receive more attention with the increasing numbers. However, real attention to the issue began only in September 2013 with the initiation of decisions directed to education of this group (Seydi, 2014). Education is provided mainly in the children's native language, where language courses in Turkish are also provided but are not compulsory. When it comes to the youth, all Syrian youth with a high school degree or those who had to stop their university studies before graduating are given the right to continue their studies in universities in Turkey without tuition or any further examinations; although for students from Turkey there are central university exams to be able to enter universities as well as tuition fees.

Even before the civil war broke out in 2011, schools in Syrian cities were struggling to manage the social and economic changes. There had already been comprehensive internal migration problems due to drought that had serious impact on the children's schooling. Therefore many of the children to have arrived from Syria had missed several years of school, partly due to the civil war and partly as a result of changes that had taken place beforehand. This made it difficult for many children to successfully complete their studies as per the school curriculum in a new country (Cochran, 2014). Providing education for refugee children is a great challenge faced by Turkey for many reasons and for several years to come. 


\section{$6.2 U S A^{19}$}

Unaccompanied refugee minors are no new phenomenon for the US - there is a long history from the Second World War onwards. See Steinbock (1989) for a comprehensive breakdown of both the legislation and number of unaccompanied refugee minors that have arrived in the US in different periods up until the end of the 1980s. During the Second World War and the years following, many children arrived from Europe. A number of children from the United Kingdom were placed in the US for the same reasons children from Finland were placed in Sweden at that time. More recently, unaccompanied refugee minors arrived from countries such as Hungary, Cuba and Vietnam, relating to events in these countries.

For a number of years, many unaccompanied minors have come to the US from different countries within Latin America. According to details from US border checks, 63,000 unaccompanied minors arrived during the period of 1 October 2013 to 31 July $2014 .{ }^{20}$ See Renwick (2014). In this period, three quarters came from three Central American countries, namely Guatemala, Honduras and El Salvador. These three countries are often referred to as "the Northern Triangle". Alongside Belize, these are the most northern countries in Central America. Migration from these three countries has dominated the influx over recent years. Before then, the majority of unaccompanied minors came from Mexico. Only a few unaccompanied minors came from other countries in Central or South America.

The total of unaccompanied minors from the Northern Triangle reached its peak in the middle of 2014 and has since decreased. An important part of the explanation for this decrease was Mexico's strengthened border surveillance of the countries to the south. However in 2015, the number of unaccompanied minors from these countries increased once more, but did not reach the same levels as in the middle of 2014. Increasing numbers of unaccompanied minors from these three countries also seek asylum in Mexico or other countries in Central America, such as Costa Rica, Nicaragua, Panama and Belize. See Rosenblum and Ball (2016).

The majority of these children from Central America arrive in one US state - Texas. Most of them are teenage boys, but some are even younger. The reasons behind the children turning to the USA primarily include violence in their home countries ${ }^{21}$, unemployment, poverty and the wish to be reunited with relatives already living there. For the children, the route through

\footnotetext{
${ }^{19}$ In this section, we build upon Stinchcomb and Hershberg (2014). See Rietig (2015) for a comparison of the scope and composition of immigration of unaccompanied minors in the USA and Europe. For a comparison of US and EU policy for unaccompanied minors, see Levinson (2011).

${ }^{20}$ The total number of arrivals is even bigger as many are not caught in border checks.

${ }^{21}$ The total number of murders per capita is very high in Guatemala, Honduras and El Salvador and significantly higher than in Costa Rica and Nicaragua for example, two other Central American countries.
} 
Mexico is incredibly dangerous. Many girls (more than three quarters) are subjected to sexual violence. Kidnappings, trafficking and disappearances are also common. Unaccompanied minors arriving in the USA from Mexico or Canada are returned immediately, whereas those from the three Central American republics have the right to have their cases considered. Generally, these considerations take a very long time - on average almost three years. The majority lives in this period with relatives or other sponsors in different parts of the USA. They have the right to attend school, but few others. The greater portion of these children spend their time living in the states where there are already many people from their three countries - mainly Texas, California, New York, Florida, Virginia and New Jersey. See Pierce (2015). Only a minority are given permission to remain in the USA. The number to be granted residence permits of those to arrive varies somewhat between the different years and depending on the three countries of origin - however only at an interval of between 10 and 14 per cent. The number to be granted permits is considerably higher amongst those who have a legal representative than those who do not. Nevertheless, most of them who are refused a permit remain in the USA and live there illegally; see Pierce (2015) and Rosenblum (2015). Unaccompanied refugee minors come to the USA from other countries than the three in Central America. The number of studies of those migrants is rather few.

Porte and Torney-Purta (1987) compare the wellbeing of Indochinese unaccompanied minors in the US. They find that that those were resettled in ethnic foster families were significantly less depressed and had higher grade-point averages than those placed in foster care with Caucasian families or in group homes.

Geltman et al. (2005) builds interviews in 2002 of a sample of 476 Sudanese minors in refugee foster care who arrived in the US in 2000 and 2001. The children showed generally high functional outcome but an important subset exhibited clinical and psychosocial problems. Most of the children functioned well in school and activities outside home, but problems appeared in their home lives.

Carlson et al. (2012) provide an overview of some studies and also include an interview with an unaccompanied boy from Sudan. In their article they stress that many unaccompanied minors are in vulnerable situations, but they also have a strength that is dependent upon both individual factors - such as support from relatives already living in the country - and support from society. 


\subsection{Other non-European countries}

There are many other countries outside of Europe that receive unaccompanied refugee minors. Here we will briefly touch upon experiences from some of these countries.

Between 2008 and 2012, Australia received 1,832 asylum seeking unaccompanied minors who had arrived by refugee boat. ${ }^{22}$ In 2013-2014, Nardone and Correa-Velez (2015) conducted interviews with 17 young men who arrived in Australia as unaccompanied refugee minors between 2009 and 2013. On arrival, they were on average 16 years old. Of the 17, 15 had originally come from Afghanistan but the majority of them had been living in Iran or Pakistan for a while, often there as refugees together with other family members. The main interview subjects included the conditions in their home country and in the country where they first fled, which had led them to flee to Australia and the journey to Australia and, amongst other things, the role the people smugglers had in it. Traumatic events characterised both of these escapes, but the reception in Australia was often also thought of as difficult. The interviews give the impression that strong individuals managed to succeed with the escape (those who did not were of course not interviewed).

Refugees who come to Australia are regularly placed in immigration detention facilities for long periods whilst waiting for a decision. Zwi and Mares (2015) have studied unaccompanied minors in such facilities. They show that the child's psychological health tends to deteriorate during the period they are there. There are substantial differences in access to health care and welfare for different groups of unaccompanied minors in Australia. See Davidson et al. (2004). The worst possibilities are for the children who have not (yet) received residence permits or have had their asylum application refused.

In Canada, unaccompanied minors first began to be noticed in 1999, when arriving from China to British Columbia by refugee boat. They sought asylum, but many disappeared (the majority most probably to the US) before their applications had been processed. Others disappeared after their asylum applications had been refused. This occurred despite the fact the conditions for reception were deemed satisfactory. One assessment that was made was that many of the children had been sent to Canada by their parents, with help from people smugglers. The aim was for them to then travel to the US to work on the black market and

\footnotetext{
${ }^{22}$ Current Australian policy states that no refugees to have come by refugee boats may be given permission to stay in the country. Now there are fewer than 1,500 of such refugees in centres on two islands outside of Australia, Manus Island (Papua New Guinea) and Nauru. The Australian government is negotiating with three countries - the Philippines, Indonesia and Malaysia - to have them receive these refugees. New Zealand has offered to take in 150 of the refugees, but Australia has rejected the offer, saying that such a transfer would lead to more refugees turning to Australia. See Hartcher (2016).
} 
that there, they were in a very vulnerable position. See Kumin and Chaikel (2002). An interview-based study conducted with 13 unaccompanied minors and ten social workers in the Québec province highlighted problems in two areas: the decision process is long and it lacks the resources adapted to the special needs of the children. See Montgomery (2002).

There is comprehensive migration of unaccompanied minors who move to find work and receive an income. Such migration takes place both within and between countries. The total number may be as high as ten million children. See an overview article by Edmonds and Shresta (2013) in which they discuss the migration of children in East Asia, from and within countries such as Bangladesh, the Philippines and Nepal. The children often work within households, down mines and in agriculture, but several also become street children with neither work nor accommodation. For details about the migration of children in ACP states (countries in Africa, the Caribbean and Pacific), see ACP Observatory on Migration (2013).

\section{Experiences from other countries than Sweden; Different phases in the migration cycle}

Here, we summarise a number of the experiences from the different countries, by discussing the different stages in the decision making and integration processes. We also discuss whether the experiences can be applied in a Swedish context.

\subsection{Asylum Examination (including the issue of determining age)}

The introductory phase is the period when the decision is made whether the unaccompanied minor will be granted asylum or not. Here, an assessment is made on aspects such as the child's age and whether they have sufficient grounds to be granted asylum. ${ }^{23}$

Many of the children who arrive and seek asylum do not have any documentation or do not have documentation that clearly states their age. The child's age is established partly through the types of information provided by the child and interviews, but also with help from different forms of medical examinations. One much debated method uses x-ray examinations of the child's teeth and parts of their skeleton. The policy differs from country to country. Using X-rays to help establish age is forbidden in England ${ }^{24}$ but is permitted in countries including France, Slovenia and Austria in certain cases. See Sedmak et al. (2015) for a

\footnotetext{
${ }^{23}$ For an overview of the process in 19 EU countries, see European Migration Network (2015c).

${ }^{24}$ And also in Ireland. See European Migration Network (2015b).
} 
comparison of the policies in these four countries. It is permitted in the Nordic countries provided that certain conditions are fulfilled.

Establishing age is important for the child on several grounds. The first is, of course, if the child is a child in the eyes of the law - i.e., under the age of 18 . If the child has turned 18 , they can also apply for asylum, but must apply as an adult. The requirements for being granted asylum can differ between adult and child asylum seekers as can the conditions that apply to different forms of support available after being granted asylum.

Even if the child is judged to be less than 18 years old and is given permission to remain in the country, the determined age is often significant to the unaccompanied minor. In certain cases, it may be advantageous to be assessed as being younger than being older; for example being judged as 16 instead of 17 . There is an advantage for the child to have several years remaining before they turn 18 . At 18 , the child is viewed as an adult in the eyes of the law and the regulations change. In a number of countries, the residence permit expires when they turn 18 and the child must apply for a new permit in good time before they turn 18 (thus as an adult asylum seeker). In the Nordic countries, this applies for unaccompanied minors in Denmark and Norway, whereas in Finland and Sweden, the permit is extended without a new application. Accommodation placement, the economic support available to the child and the municipality responsible for the child are other aspects that changes in the different reception countries when the child turns 18. See European Migration Network (2015a) and EMN (2015) for a short version of the rules for support that apply for the unaccompanied minors that turn 18. In some countries, the special support ends at this age, whereas in the other countries, it continues until the child becomes older (until they turn 20,21 or 25 ).

One study of Afghan unaccompanied minors in the United Kingdom (Robinson and Williams, 2015) shows the problems these children face when they turn 18 and no longer have the right to remain in the country - and must be prepared to leave - when they become adult in the eyes of the law.

The age that is established can also be significant for the younger children. In a number of countries there are age limits - e.g. 15 years - for the type of accommodation placement the child may have and the forms of economic support from the state to the local regions. However attention must be drawn to the fact that it may not always be advantageous to be assigned a lower age than is correct. For example, the level at which they are placed in school may be too low. 
In a comparison of different EU countries (European Migration Network, 2015a), Belgium is hailed as the country with the system that shows the most respect to the child's rights when they are determining the age. If there is uncertainty surrounding a child's age, three different types of x-ray examinations are conducted. The results of the test returning the lowest age then forms the basis of the evaluation. Based on the expected values of this test, a standard deviation is then calculated (no test can provide an exact estimation). This then becomes the assigned age, unless the child has stated they are older. It does not mean that efforts should be made to achieve this. On the contrary, it means that the systems in other countries are even more restrictive. In some countries, participation in x-ray examinations may formally be voluntary, however at the same time it may mean that the child then becomes classified as an adult if they refuse to be tested (in practice, volunteering may be incongruous).

An important part of the introductory phase is to determine the child's situation in the country from where they came. Is it so severe that it forms a substantial basis for the child being granted a permit, or is the child to be returned to their home country? The evidence - which essentially is the only evidence available - is interviews with the children seeking asylum. These are difficult to conduct, and should comprise repeated interviews. There are methods and manuals for how these types of interviews should be conducted. See Given Wilson and Gyulai (2015).

A third part of the introductory phase is to ensure that a person or authority is appointed to take care of the child's interests. There are almost as many different models for this as there are countries within the EU. See European Migration Network (2015d). This is important perhaps especially as the unaccompanied minors often have problems with trust - considering what they have been through and that they do not know the society in which they have arrived. See Ní Raghallaigh, (2013). For an interview study of people in Flanders who have been appointed to represent and help unaccompanied minors (i.e., the equivalent of the appointed guardians in Sweden), see De Graeve, (2015). The study indicates that the people who have taken up such a task are often highly involved with helping the children they represent.

One particular problem is that very often, those who are guardians/trustees/contact persons do not speak the same language as the child and so an interpreter must be used. This can lead to problems, especially when the interpreter lacks sufficient skills. They may omit things the child says or change their meaning. See Kjelaas and Eide (2015), who present the results from a study of interpreting during interviews of unaccompanied minors that emphasise the 
importance of enlisting qualified interpreters in Norway, and Keselman et al. (2010a, 2010b) for a similar study of interpretation for refugee minors in in Sweden with the same types of serious mistakes. An alternative solution is, of course, appointing guardians/trustees/contact persons who speak the same language as the child when possible.

\subsection{Accommodation placement}

A common result in many of the international studies is that accommodation placement is critical for the integration and well-being of the children. It differs significantly between the various countries. Most of all, this applies to the introductory phase where there may be anything from detention centres to forms of housing that are distinctively more integrated into the community. One aspect that is highlighted in a number of the studies, are the problems that children may face when being transferred between the different forms of accommodation. Those who are responsible for the accommodation and the various contact persons linked to it are often believed to be very important to the child - as "acting parents". The people who live with the children are also important. Are they from the same country and the same (ethnic, religious, political) groups?

\subsection{Education}

Most unaccompanied refugee minors arrive when they are of school age. The majority of them are of an age that - for the majority of the other children in the country - would involve upper-secondary school studies. The unaccompanied minors may be at this level, but in many cases, they may also be at lower or much lower levels. In a number of cases, they come from countries (home country or transit country) where they have received inadequate teaching. In such cases, this means that they need to begin at a lower level than would correspond to their age. It is important for the children to be placed at the right levels. However this often means that they complete the level of education at a higher age than those who were born in the country. Generally - but not always - the unaccompanied minors receive tuition in the language of the host country.

Research indicates that children benefit from teaching in their mother tongue, while they are studying the host country language at the same time. Teaching is done more effectively and efficiently when it is taught in the language that the child has a good cognitive understanding. When the child arrive aged 15-17 education in a second language, where the child has lower 
proficiency, does not allow the child to continue education at its level of knowledge and cognitive understanding. Thus, research indicates that simultaneous education in both languages has positive effects to all learning since it activates the brain and the learning process in a different way (Eriksson, 2002). Preparatory classes might take up to several years. The individual assessments of the newly arrived in relation to level of knowledge and interest are also seldom done partly due to the strong focus on the host country language in the school system, something that has consequences for several aspects of the schooling of new arrivers (Brendler-Lindquist and Hjern, 2010). Different types of preparatory tuition may be available for this group. One potential disadvantage of such preparatory teaching is that they do not meet with non-refugees of the same age and so it could take longer for them to become integrated into society. However, there are several invisible barriers immigrants usually face with regard to forming friendships, intimate relationships with the majority group (Çelikaksoy, 2016). Thus, having international friends and being in an international environment, where the host country language is the common language is also a way of integration.

\subsection{Work}

We have only found studies that examine the situation for unaccompanied refugee minors establishing themselves on the labour market for Sweden and Norway. One explanation for this is that this comprehensive immigration of unaccompanied refugee minors is a relatively new phenomenon in many countries and therefore few have reached the age at which people commonly establish themselves on the labour market. Instead, the studies discuss the introductory phase, hence predominantly the children's health and also their accommodation. Another explanation is that outside of the Nordic countries, there is no data register with details about the unaccompanied minors. The studies therefore focus upon the periods the children are still children (i.e., under 18) when it is easier for the researchers to establish contact via their accommodation, municipalities or other institutions that have regular contact with the children.

The Norwegian studies note the same things as our studies focusing on Sweden. ${ }^{25}$ The unaccompanied refugee children have lower levels of employment than the remainder of the Norwegian population and their incomes are lower. Levels of employment increase alongside

\footnotetext{
${ }^{25}$ See Çelikaksoy and Wadensjö (2015a, b, c and d) for results from our study.
} 
the number of years spent in Norway. Often, there are more boys in employment than girls. The unaccompanied minors are overrepresented within all professions in the service sector. Levels of employment are higher amongst those living in Oslo - where Norway's labour market is strongest - than in other parts of the country. The results are similar to those for Sweden; the level of employment is higher in Stockholm. There are as in Sweden also clear differences in the share of minors in employment based upon the country from which they have arrived.

For the experiences in England regarding the transition to the labour market, see a survey by Wade (2011). The survey mainly covers qualitative studies.

\subsection{Health $^{26}$}

The health of the unaccompanied minors is the issue that is most often discussed in research concerning this group. First and foremost it deals with their psychological health. Here, we can only present a small portion of the many results from this research.

There are researchers who believe that there is an overemphasis on this matter. See Summerfield (1999). In an overview of the research about unaccompanied minors, Wernesjö (2011) expresses that too much emphasis is placed on the health problems they face as a consequence of traumatic experiences. She believes that the factors that appear to safeguard the child and their environment should also be highlighted. Many of the children show high competence in various respects.

There are many factors that can influence the psychological health of unaccompanied minors. ${ }^{27}$ To begin with, the experiences in the home country that have led to their escape; Secondly, the other experiences during the escape; Thirdly, the uncertainty faced after arrival that surrounds whether the residence permit will be granted or not; Finally, the environment in the receiving country is unfamiliar when compared to that of their home country, and they can also encounter different types of discrimination. These factors can subsequently be divided into different subcomponents. See Fazel and Stein (2002) for such an analysis with the focus on examples taken from the United Kingdom. On the other hand, the weakest children are not

\footnotetext{
${ }^{26} \mathrm{We}$ do not include studies that discuss the health of children when they arrive together with their parents and receive asylum at the same time. For such studies, see e.g., Nielsen et al. (2008) and Montgomery (2010) regarding the situation in Denmark and Aronsson et al. (2009) for Sweden.

${ }^{27}$ For a survey see Fazel et al. (2012).
} 
those to successfully complete a complicated, often dangerous escape. Not all of them have health problems.

One study conducted shortly after the arrival of a number of unaccompanied minors in Norway (204 children) and Belgium (103 children) suggests that many of them have post traumatic stress or depression. See Vervliet et al. (2014). This indicates that the children need support as soon as they arrive and also that follow ups are made to see what is happening later on during their stay in the new country.

Eide and Hjern (2013) provide an overview of studies from a few western countries that suggest that the problems that were present upon arrival decrease over time and the unaccompanied minors - for example, in Norway - achieve the same results in education and on the labour market as other children in Norway with foreign backgrounds.

Nevertheless, many studies point out that the children's mental health problems are longlasting - almost two years; see Bean et al. (2007), Jensen et al. (2014) and Vervliet et al. (2014) who report studies regarding the Netherlands, Norway and Belgium respectively. Manhica et al. (in press) point towards the importance of cultural competence within psychiatry, in order to better understand the difficulties faced by the children and provide them with the relevant care.

A study of 32 boys - 18 unaccompanied and 14 other refugees - granted asylum in southern Germany showed that post-traumatic stress as well as feelings of guilt and shame was more common amongst the unaccompanied minors than those who had arrived with their parents. See Stotz et al. (2015).

The Danish Refugee Council (2011) presents a survey of studies of different types of treatment for various mental health problems amongst refugee children and young people.

Only one of 44 studies thoroughly presented in the overview purely deals with unaccompanied refugee children (that study discusses the conditions for a number of Sudanese children who have arrived in the US).

\section{Concluding analysis}

Here, we present a concluding analysis based on our survey. With help from this analysis, we have tried to point to the conclusions that can be drawn from the investigations and studies we present. They are predominantly qualitative. Is it possible to see which types of 
measures/policy can have positive effects? And is it possible to see where the problems are especially found? This in turn may form the basis for a discussion on continued studies of, for example, particularly vulnerable children and also about the possibilities available for various measures to improve the circumstances for these children.

One general conclusion that has been reached by many researchers is that in groups of unaccompanied minors, there are many who are affected by traumatic events - however there are also many who display significant strength and ability to manage their lives in a new country. We will keep this in mind when we present our conclusions for the various subsections below.

One first conclusion is that the initial phase is important. It is important that asylum examination is fast, but must still be of a high quality. The waiting period whilst a decision is made is difficult for the children and should therefore, based on this and other reasons, be as short as possible. It is important that the examination is conducted in a way that shows respect to the child. The children who arrive have often undergone traumatic experiences and it is important that adequate care measures are taken as early as possible.

Another conclusion is that it is important to map the level of education (schooling, vocational) the child already has when they arrive and that education is adapted to their existing knowledge. It is also very important that teaching of the language of the host country is efficient.

One third conclusion is that it is important that the accommodation placement is adapted to the child's age and gender, and with an awareness of the presence of ethnic/religious conflicts and of the child's need for support. It is also important that there is continuity with the placement and changes made as the child becomes older.

One fourth conclusion is that it is important for the child to have contact both with people from their own ethnic group and with people who belong to the majority-group of the population.

A fifth conclusion is that entry into the labour market can often be difficult due to a lack of knowledge of the child's host country's language. This continues to underline the importance of host country language education. We also want to highlight differences between boys' and girls' entry into the labour market. Boys establish themselves on the labour market to a considerably greater extent. 
We will now attempt to bring forward some of the results from the review in a little more detail, by using a list of potential measures for improving the reception of the unaccompanied minors. Here, we will also build upon the various experiences that have been presented to us whilst we have presented our previous studies.

\section{A list of suitable measures}

\section{Arrival}

a. Rapidly receiving further placement. It is important that the stay in arrival accommodation is as brief as possible.

b. An important issue is assessing the age of those to arrive as asylum-seeking minors and that this is done with respect.

c. Be aware of the tensions between different groups. It is important that the placements are organised so groups of individuals with internal conflicts of ethnic, religious or political natures or, of different ages and genders are not placed in the same accommodation. Alternatively, that the personnel have the skills to manage these conflicts and other problems should they arise.

d. Arrival accommodation. It is important that there are structured activities for the residents and that they have contact persons.

e. Who has serious problems? As soon as they arrive at the arrival accommodation it is important to find out who has serious medical (psychiatric) problems and that they receive adequate treatment as soon as possible.

2. First placement

a. Guardian/appointed custodian. It is important that all unaccompanied minors receive a guardian and once they have been granted a residence permit, that they receive an appointed custodian (often the same person who was their guardian). Those who have been appointed must have adequate training, not have responsibility for many children and ideally, have knowledge of the unaccompanied minor's native language (otherwise a competent interpreter). It is important that special training is given for those who are appointed as guardians. 
b. A contact person from the host society is crucial for these children to be able to navigate in the society and therefore build a future; as such, the loss of their guardian/specially appointed custodian when they turn 18 can hinder their integration. Continuing the support until the age of 21 would give the unaccompanied minors better chance of establishing themselves in society.

c. Qualified interpreters. It is important that the interpreters are qualified and they interpret from the child's own language (and not that which is predominantly spoken in the child's country of origin).

d. Examining grounds for asylum. It is important that the examination of the grounds for asylum are conducted in a legally sound manner and as quickly as possible, to reduce the period of uncertainty.

3. Accommodation

a. It is important that the accommodation is adapted to the needs of the child.

b. It is important that the accommodation personnel can help the children with their homework and generally provide support with their studies.

c. Foster family/foster home. The suitability of a foster family must be thoroughly examined before they can assume responsibility for the unaccompanied child.

d. Private accommodation. The same suitability requirements should apply for the placement of the child with a relative or other connection provided by the child.

e. Regardless of the type of housing the child has, it is important that should different kinds of poor treatment arise, the child must be able to go to one of the forms of accommodation, regardless of establishment, where they can seek and receive help. They should be able to do this even after they have turned 18. All children must be informed of this and how contact is to be made in different ways and on different occasions.

f. Networks are important and therefore it is important that the accommodation can help the child establish contacts in different ways.

g. There is the risk of different forms of discrimination, even within the accommodation. It is important to be aware of this. 


\section{Education}

a. Language training. It is very important to the child's integration that they receive education in the host country language as soon as possible at a level that is best suited to the child.

b. Introductory education. At the same time, it is important that there is simultaneous education that provides an introduction to host country society. It is also important that such education is directly related to the child's own situation, e.g., about education, the labour market and support after they have reached adult age.

c. Placement at the right level. A thorough mapping of the child's knowledge level is required upon their arrival to be able to place them at the right level in the school system.

d. Education that continues into a higher age. As the majority of children arrive aged 16 and 17 , it is difficult for them to complete their upper-secondary education at the regular age. In such a case, it is important that they can continue and complete their education.

e. The child must have the opportunity to receive advice early on about the possibilities of combining work and education, and the possibility to return to education after a period of employment.

f. Contact with peers. Peer-to-peer contact, both with other refugee children (bonding social capital) and other children (bridging social capital) is important for integration.

g. Careers guidance. The children lack knowledge about how the host country labour market works. Study and careers guidance is therefore especially important for the unaccompanied minors. It is important that the guidance counsellor has been fully trained to be able to provide better advice to unaccompanied minors. Teachers also need such a form of supplementary training.

5. Work

a. It is important to inform the child of how to look for work, how to write a CV, how to behave during an interview and also about the possibilities to combine studying with working. 
b. Internship Different types of internship during their time at school can provide increased knowledge of the host country labour market.

c. Different types of work are suitable for minors with different circumstances. It is particularly important to help those who arrive late on in their teenage years to find their first job.

d. Youth work - dead end jobs. If their first job is unqualified work, it can become a dead end job. It is essential to help the child move on from this type of work. 


\section{References}

Aalandslid, Vebjørn and Anette Walstad Enes (2012), "Enslige mindreårige flyktninger i arbeid og utdanning”, Statistics Norway, Oslo, Report 13/2012.

Ackerman, Xanthe, Sarah Dryden-Peterson and Maysa Jalbout (2014) "A fourth year of war in Syria: What we still need to know about educating refugees”, Brookings Institute, $2014 / 03 / 14$

ACP Observatory on Migration (2013), "The migration of children in ACP countries: Of their own free will or involuntary?” Background Note ACPOBS/2013/BN10.

Akademikerförbundet SSR (2015), “Öppet Sverige - Förslag för en bättre migrationsprocess", Delrapport om ensamkommande barn.

Andersson, Matilda and Igor Petrov (2015), "Ensam i Europa? En studie om mottagande- och anpassningsprocessen för ensamkommande barn i Europa, med utgångspunkt i Italien”, Malmö University, Faculty of Health and Society.

Andersson-Brynja, Nina and Roy Melchert (2010), "Nyanlända elevers utbildning - Goda Exempel från Tio Kommuner”, Swedish Association of Local Authorities and Regions. Aronsson, Bernice, C Wiberg, Per Sandstedt and Anders Hjern (2009), “Asylum-seeking children with severe loss of activities of daily living: clinical signs and course during rehabilitation”, Acta Pcediatrica, Vol. 98(12), pp. 1977-1981.

Association of Local Authorities, Stockholm (2013), Ensamkommande barn och unga i Stockholms län. Resultat av det arbete som bedrevs av samtliga 26 kommuner under tiden nov 2010 - dec 2012, Stockholm: Association of Local Authorities.

Atasu Topcuoglu, Reyan (2012), "Profiling Migrant Children in Turkey, Social Policy and Social Works Suggestions a Rapid Assessment”, SIDA and IOM Report.

Backlund, Åsa, Riitta Eriksson, Katarina von Greiff and Eva-Marie Åkerlund (2012), "Ensam och flyktingbarn - barnet och socialtjänsten om den första tiden i Sverige”, FOU-Södertörn, Research report 2012:1.

Ombudsman for Children in Sweden (2016), "Barn på flykt. Barns och ungas röster om mottagandet av ensamkommande", Stockholm: Ombudsman for Children in Sweden. 
Bean, Tammy M., Elisabeth Eurelings-Bontekoe and Philip Spinhoven (2007), "Course and predictors of mental health of unaccompanied refugee minors in the Netherlands: One year follow-up", Social Science \& Medicine, Vol. 64(6), pp. 1204-1225.

Björklund, Krister (2015), “Unaccompanied refugee minors in Finland. Challenges and good practices in a Nordic context”, Migration studies C 26, Institute of Migration, Turku.

Bhabha, Jacqueline (2004) "Seeking Asylum Alone: Treatment of Separated and Trafficked Children in Need of Refugee Protection”, International Migration, Vol. 42(1), pp. 141-148.

Blom, Lisa (2008), “Upplevda möjligheter och hinder i samverkansprocessen kring mottagandet av ensamkommande barn och ungdomar", Socialmedicinsk tidskrift, Vol. 85(6), pp. 192-204.

Brendler-Lindqvist, Monica (2004), Att möta de ensamkommande barnen. Stockholm: Save the Children.

Brendler-Lindquist, Maria and Hjern, Anders (2010), "Reception of asylum seeking and refugee children in the Nordic countries - The Swedish Report", The Swedish Report. Report Updated 26.11.2010.

Bunar, Nihad (2012) "Utvärdering av projektet Ensamkommande barn i Stockholms län:

Samordning av kommunstöd och kommunsamarbete", KSL, Association of Local Authorities, Stockholm.

Carlson, Bonnie E., Joanne Cacciatore and Barbara Klimek (2012), “A Risk and Resilience Perspective on Unaccompanied Refugee Minors", Social Work, Vol. 57(3), pp. 259-269.

Çelikaksoy, Aycan (2016), "Household formation behavior: An analysis of relative education and exogamy for descendants of immigrants in Sweden", Ethnicities, Vol. 16(4), pp. 547567.

Çelikaksoy, Aycan and Eskil Wadensjö (2015a), “Unaccompanied Minors and Separated Refugee Children in Sweden: An Outlook on Demography, Education and Employment”, IZA DP 8963.

Çelikaksoy, Aycan and Eskil Wadensjö (2015b), “The Unaccompanied Refugee Minors and the Swedish Labour Market”, IZA DP 9306.

Çelikaksoy, Aycan and Eskil Wadensjö (2015c), "Ensamkommande barn i Sverige”, SULCIS Report series 2015:1. 
Çelikaksoy, Aycan and Eskil Wadensjö (2015d), "De ensamkommande flyktingbarnen och den svenska arbetsmarknaden", SULCIS Report series 2015:2.

Çelikaksoy, Aycan and Eskil Wadensjö (2015e), "Hur går det för de ensamkommande flyktingbarnen?", Dagens Samhälle, 30 August 2015

http://www.dagenssamhalle.se/debatt/hur-gar-det-foer-de-ensamkommande-flyktingbarnen$\underline{17778}$

Çelikaksoy, Aycan and Eskil Wadensjö (2015f), "Vägen till arbetsmarknaden”, Socionomen, no. 7 , pp. 16-21.

Çelikaksoy, Aycan and Eskil Wadensjö (2016), "Hur har de ensamkommande barnen det i Sverige?", Socialmedicinsk tidskrift, vol. 93(1), pp. 28-36.

Christensen, Else (2006), “Uledsagede asylansøgerbørn”, The Danish National Centre for Social Research, Copenhagen, Report 06:34.

Cochran, Judith (2014), "The Education of Syrian Refugee Children", The Middle East Institute Report.

Dalgard, Anne Berit (2016), "Enslige mindreårige flyktninger i arbeid og utdanning, 2014, 90 prosent fra Afghanistan i arbeid og utdanning efter fire år”, Statistisk sentralbyrå 14 mars 2016.

Dansk Flygtningehjælp (2011), ’Flygtningebørn - virkningsfulde indsatser.

Forskningregistrant om psykosociale interventioner for børn og unge med flygtningebaggrund", Copenhagen.

Davidson, N, S. Skull, D. Burgner, P. Kelly, S. Raman, D. Silove, Z. Steel, R. Vora and M. Smith (2004), "An issue of access: Delivering equitable health care for newly arrived refugee children in Australia”, Journal of Pediatrics and Child Health, Vol. 40(2), pp. 569575 .

De Graeve, Katrien (2015), “Classed Landscapes of Care and Belonging: Guardianships of Unaccompanied Minors”, Journal of Refugee Studies, doi: 10.1093/jrs/fev011.

Derluyn, Ilse and Eric Broekaert (2008), "Unaccompanied Refugee Children and Adolescents: The Glaring Contrast between a Legal and a Psychological Perspective", International Journal of Law and Psychiatry, Vol. 31(4), pp. 319-330. 
Derluyn, Ilse and Marianne Vervliet (2012), "The wellbeing of unaccompanied refugee minors" in D. Ingleby, A. Krasnik, V. Lorant and O. Razum (eds.), Health inequalities and risk factors among migrants and ethnic minorities. Vol. 1, Antwerpen/Apeldoorn: Garant, pp. 95-109.

Derluyn, Ilse, Eric Broekaert and Gilberte Schuyten (2008b), "Emotional and behavioural problems in migrants adolescents in Belgium”, European Child \& Adolescent Psychiatry, Vol. 17(1), pp. 54-62.

Edmonds, Eric V. and Maheshvor Shresta (2013), "Independent child labor migrants" in Amelie F. Constant and Klaus F. Zimmermann (eds.), International Handbook on the Economics of Migration, Edward Elgar, Cheltenham, UK and Northampton, MA, USA.

Eide, Ketil (2000), "Barn i bevegelse. Om oppvekst og levekår for enslige mindreårige flyktninger", University College of Southeast Norway, Faculty of Health and Social Studies.

Eide, Ketil and Anders Hjern (2013), “Unaccompanied refugee children - vulnerability and agency”, Acta Pcediatrica, Vol. 102(7), pp. 666-668.

Ekenberg, Kerstin (2011), "Ensamkommande barn i Stockholms län - utbildning. Rapport kartläggning: Nya mål för det fortsatta arbetet”, Association of Local Authorities, Stockholm. EMN (2014), Annual Report on Migration and Asylum Policy. Finland 2014, Helsinki:

Euroopan muuttoliikeverkosto (EMN).

EMN (2015), EMN INFORM, "Policies, practices and data on unaccompanied minors in the EU Member States and Norway”, May 2015.

EMN (2015a), "Nyckeltal om Migration 2014”, Helsinki: European Migration Network, the Finnish Immigration Service.

EMN (2016), Arlig rapport om migrations- och asylpolitik. Finland 2015, Helsingfors:

Europeiska migrationsnätverket.

Erden, Gülsen and Gökçe Gurdil (2009) "Savas Yasantilarinin ardindan Cocuk ve Ergenlerde Gozlenen Travma Tepkileri ve Psiko-Sosyal Yardim Onerileri, Turk Psikoloji Yazilari, Vol. 12(24), pp. 1-13.

Eriksson, Malin, Mehdi Ghazinour, Anders Hanberger, Joakim Isaksson and Malin E. Wimelius (2014), Utvärdering av insatser för ensamkommande barn och ungdomar i Umeå 2012-2013, Final report, Umeå Centre for Evaluation Research, Umeå University. 
Eriksson, Riitta (2013), ”Ensamt barn på flykt i Sverige”, Report, Institute of Migration, Turku.

ESPON (2015), “Territorial and urban aspects of migration and refugee inflow”, ESPON Policy Brief No. 2.

European Migration Network (2015a), "Policies, practices and data on unaccompanied minors in the EU Member States and Norway. Synthesis Report”, May 2015.

European Migration Network (2015b), "Policies, practices and data on unaccompanied minors in the EU Member States and Norway. Annexes to the Synthesis Report”, May 2015. European Migration Network (2015c), "LT Ad-Hoc Query on Foreigners who claim to be minors but whose age is not confirmed." Requested by LT NCP on $23^{\text {rd }}$ October 2014. Compilation produced on $29^{\text {th }}$ December 2015 (responses from 19 countries).

European Migration Network (2015d), “Ad-Hoc Query on admission/residence and guardianship related provisions and for unaccompanied foreign and/or EU minors in vulnerable situations.” Requested by BE EMN NCP on 18 November 2013. Compilation produced on 16th January 2014 (responses from 16 countries).

Eurostat (2015), European Statistics on Migration.

Eurostat (2016), “Almost 90000 unaccompanied minors among asylum seekers registered in the EU in 2015", Press release, 2 May 2016.

Fazel, Mina and Alan Stein (2002), "The mental health of refugee children", Archives of Disease in Childhood, Vol. 87(5), pp. 366-370.

Fazel, Mina, Ruth V. Reed, Catherine Panter-Brick and Alan Stein (2012),’Mental health of displaced and refugee children in high-income countries: risk and protective factors", No. 379, pp. 266-282.

Folkhögskolespåret (2016), "Lägesrapporter”.

FRR (2012) “Federation of Rights of Refugees Report on Turkey”, FRR Report.

Fälldin, Kerstin and Görel Strand (2010), Ensamkommande barn och ungdomar: en praktisk handbok om flyktingbarn, Stockholm: Natur \& Kultur.

Geltman, Paul L., Wanda Grant-Knight, Supriya D. Metha, Christine Lloyd-Travaglini, Stuart Lustig, Jeanne M. Landgraf and Paul H. Wise (2005), "The "Lost Boys of Sudan". 
Functional and Behavioral Health of Unaccompanied Refugee Minors Resettled in the United States", Arch Pediatr Adolesc Med, Vol. 159(6), pp. 585-591.

Given Wilson, Zoe and Gabor Gyulai (2015), "Credibility Assessment in Children”, Chapter 12 in Gabor Gyulai (ed.), Assessment in Asylum Procedures: A Multidisciplinary Training Manual. Volume Two. Budapest: Hungarian Helsinki Committee.

Green, Eva (2000), "Unaccompanied Children in the Danish Asylum Process - Experience from Legal Counselling of and Assistance to Children”, Danish Refugee Council, Copenhagen.

Hartcher, Peter (2016), “PM's new asylum push”, The Sydney Morning Herald, February 2021, 2016, pp. 1 and 6.

Haugen, John Åge and Tone Dyrhaug (2014) "Enslige mindreårige flyktninger i barnevernet 2011”, Statistics Norway, Report 2014/7.

Hessle, Marie (2009), Ensamkommande men inte ensamma: Tioårsuppföljning av ensamkommande asylsökandes flyktingbarns livsvillkor och erfarenheter som unga vuxna i Sverige, Doctoral thesis, Department of Education, Stockholm University.

Hirvonen, Katrina (2013), “Sweden when hate becomes norm”, Race \& Class, Vol. 55(1), pp. 78-86.

Hjeds Löfmark, Monika and Jonas Eriksson (2016), "Människohandel i EU. En studie av destinationsländer”, SIEPS Report 2016:2

Hjern, Anders and Henry Ascher (2015), “Svårt att säkert fastställa ålder hos barn”, Läkartidningen, 2015;112:DRFZ.

Hjern, Anders, Maria Brendler-Lindqvist and Marie Norredam (2012), “Age assessment of young asylum seekers", Acta Pcediatrica, Vol. 101(1), pp. 4-7.

Human Rights Watch (2016), Att söka skydd. Ensamkommande barn i Sverige International Organization for Migration (IOM) (2015), "Discussion Paper for the Expert Meeting on Unaccompanied Minor Asylum Seekers”, Eastern Partnership, Panel on Migration and Asylum, Kiev 21- 22 October 2015.

Iveroth, Karin (2015), “Ett segregerat mottagande? En explorativ studie om flyktingbarns integration på den svenska arbetsmarknaden", Department of Political Science, University of Gothenburg. 
IVO (2015), "IVO:s tillsyn av HVB för barn och unga 2014 och 2015", powerpoint presentation.

Jensen, Tine K., Envor M Bjørgo Skårdalsmo and Krister W. Fjermestad (2014), "Development of mental health problems - a follow-up study of unaccompanied refugee minors", Child and Adolescent Psychiatry and Mental Health, No. 8:29.

Keselman, Olga, Ann-Christin Cederborg and Per Linell (2010a), “"That is not necessary for you to know!' Negotiation of participation status of unaccompanied children in interpretermediated asylum hearings", Interpreting, Vol 12(1), pp. 83-104.

Keselman, Olga, Ann-Christin Cederborg, Michael E. Lamb and Örjan Dahlström (2010b),"Asylum-seeking minors in interpreter-mediated interviews: what do they say and what happens to their responses", Child and Family Social Work, Vol 15(3), pp. 325-334. Kjelaas, Irmelin and Ketil Eide (2015), "Barnets stemme i tolkemedierte samtaler”, Norges Barnevern, Vol. 92(2), pp. 108-122.

Kopparberg, Saskia (2014), "Unaccompanied Minors in Austria. Legislation, Practices and Statistics", Vienna: International Organization for Migration (IOM).

Kullander, Mats, Lisa Tönnes Lönnroos, Natalie Verständig and Tor Egil Viblemo (2016), “Ensamkommande barn som försvinner - nulägesanalys”, Report 2016:1, Stockholm County Administrative Board.

Kumin, Judith and Danya Chaikel (2002), "Taking the Agenda Forward: The Roundtable on Separated Children Seeking Asylum in Canada", Refuge, Vol. 20(2), pp. 73-77.

Lang, Annika and Renata Popadic (2016), "The Scum of the Earth. En studie om gatubarnen från Nordvästra Afrika”, FOU enheten vid Baggium Vård \& Behandling AB.

Levinsin, Amanda (2011), "Unaccompanied Immigrant Children: A Growing Phenomenon with Few Easy Solutions”, Migration Policy Institute, Feature January 24, 2011.

Lidén, Gustav and Jon Nyhlén (2015), “Structure and Agency in Swedish Municipalities' Reception of Unaccompanied Minors”, Journal of Refugee Studies, doi: 10.1093/jrs/fev015. Luster, Tom, Desiree Qin, Laura Bates, Meenal Rana and Jung Ah Lee (2010), "Successful adaption among Sudanese unaccompanied minors: Perspectives of youth and foster parents", Childhood, Vol. 17(2), pp. 197-211. 
Malmsten, Jenny (2014), "Unaccompanied children living in transitional houses - voices from Sweden", International Journal of Migration, Health and Social Care, Vol. 10(1), pp. 18-35. Manhica, Hélio Adelino, Ylva B. Almqvist, Mikael Rostila and Anders Hjern (in press), "The use of psychiatric services by young adults who came to Sweden as teenage refugees: a national cohort study", Epidemiology and Psychiatric Sciences.

Marquardt, Luisa, Alexander Krämer, Florian Fischer and Luise Prüfer-Krämer (2015), "Health status and disease burden of unaccompanied asylum-seeking adolescents in Bielefeld, Germany: cross-sectional pilot study, Tropical Medicine and International Health, doi:10.1111/tmi.12649.

McDonald, J. (1995), “Entitled to Learn? Report on Young Refugees’ Experiences of Access and Progression in the UK Education System", World University Service, London.

Montgomery, Catherine (2002), "The "Brown Paper Syndrome": Unaccompanied Minors and Questions of Status", Refuge, Vol 20(2), pp. 56-67.

Montgomery, Edith (2010), “Trauma and resilience in young refugees: A 9-year follow-up study", Development and Psychopathology, Vol. 22(2), pp. 477-489.

Müller, Andreas (2014) “Unaccompanied Minors in Germany - Study by the German National Contact Point for the European Migration Network (EMN)", Nürnberg: Federal Office for Migration and Refugees (BAMF).

Nardone, Mariana and Ignacio Correa-Velez (2015), "Unpredictability, Invisibility and Vulnerability: Unaccompanied Asylum-Seeking Minors' Journeys to Australia", Journal of Refugee Studies, doi:10.1093/jrs/fev020.

Ní Raghallaigh, Muireann (2013), “The causes of mistrust amongst asylum seekers and refugees: Insights from research with unaccompanied asylum-seeking minors living in the Republic of Ireland”, Journal of Refugee Studies, Vol. 27(1), pp. 82-100.

Nielsen, Signe S., Marie Norredam, Karen L. Christiansen, Carsten Obel, Jørgen Hilden and Allan Krasnik (2008), "Mental health among children seeking asylum in Denmark - the effect of length of stay and number of relocations: a cross-sectional study", BMC Public Health, Vol. 8: 293.

Niemeyer, Maya (2015), “The Cultural and Social Capital of Unaccompanied Refugee Children. A policy study of the education of unaccompanied refugee children in Sweden and 
Germany”, Institute of International Education, Department of Education, Stockholm University.

Olze, A., W. Resinger, G. Geserick and A. Schmeling (2006), “Age estimation of unaccompanied minors. Part II. Dental aspects”, Forensic Science International, 159S, S65S67.

Oppedal, Brit and Thormod Idsoe (2015), "The role of social support in the acculturation and mental health of unaccompanied minor asylum seekers", Scandinavian Journal of Psychology, DOI:10.1111/sjop.12194.

Özpolat-Olgun, Tuba and Shaika Yuksel (2001) "Yakinlarini Kaybeden Kisilerin Ruhsal Durumlarinin ve Yas Tepkilerinin Karsilastirilmasi”, Toplum ve Bilim, Vol. 90(1), pp. 41-69. Paksuniemi, Merja (2015), "Finnish refugee children's experience of Swedish refugee camps during the Second World War", Migration Letters, Vol. 12(1), pp. 28-37.

Parusel, Bernd, "Unaccompanied Minors in Germany: Reception, return and integration arrangements", Working Paper 26, Federal Office for Migration and Refugees and European Migration Network.

Pierce, Sarah (2015), Unaccompanied Child Migrants in U.S. Communities, Immigration Court, and Schools, Washington, DC: Migration Policy Institute.

Porte, Zelda and Judith Torney-Purta (1987), “Depression and Academic Achievement among Indochinese Refugee Unaccompanied Minors in Ethnic and Nonethnic Placements", Amer. J. Orthopsychiat., Vol. 57(4), pp. 536-547.

Ramel, Björn and Karima Assel (2015), "Ensamkommande bör få mer stöd - inte mindre”, Svenska Dagbladet, 30 November 2015.

Ramel, Björn, Jakob Täljemark, Anna Lindgren and Björn Axel Johansson (2015), "Overrepresentation of unaccompanied refugee minors in inpatient psychiatric care", SpringerPlus, (2015) 4:131, DOI 10.1186/s40064-015-0902-1.

Refugee Council (1999), "Report on Helping Refugee Children in Schools”, London: Yale Press.

Renwick, Danielle (2014), “The U.S. Child Migrant Influx”, Council of Foreign Relations. 
Rietig, Victoria (2015), “Top 10 of 2015 - Issue \#8: A shared challenge: Europe and the United States confront significant flows of unaccompanied child migrants", Washington, DC: Migration Policy Institute.

Robinson, Kim and Lucy Williams (2015), "Leaving Care: Unaccompanied Asylum-Seeking Young Afghans Facing Return”, Refuge, Vol. 31(2), pp. 85-94.

Rosenblum, Marc R. (2015), Unaccompanied Child Migration to the United States. The Tension between Protection and Prevention, Washington, DC: Migration Policy Institute. Rosenblum, Marc R. and Isabel Ball (2016), Trends in Unaccompanied Child and Family Migration from Central America, Washington, DC: Migration Policy Institute.

Ryan, Kelly (2014), “Unaccompanied and separated minors: A call for a multidisciplinary response to a humanitarian crisis”, Migration Policy Practice, Vol. 4(3), pp. 4-10.

Santavirta Torsten, Nina Santavirta, Theresa S. Betancourt and Stephen E. Gilman (2015), "Long term mental health outcomes of Finnish children evacuated to Swedish families during the second world war and their non-evacuated siblings: cohort study", British Medical Journal, 2015;350:g7753 doi: 10.1136/bmj.g7753

Save the Children Denmark (2010), "Det sværeste var at være ensom... Udfordringer for uledsagede flygningebørn i Danmark."

Schmeling, A., W. Resinger, G. Geserick and A. Olze (2006), “Age estimation of unaccompanied minors. Part I. General considerations”, Forensic Science International, 159S, S61-S64.

Sedmak, Mateja, Tjaša Žakelj, Blaž Lenarčič and Zorana Medarič (2015), “In whose best interests? Exploring Unaccompanied Minors' Rights through the Lens of Migration and Asylum Processes (MinAs)", Comparative analysis of the national reports on the state of the art, University of Primorska, Science and Research Centre.

Seglem, Karoline B., Brit Oppedal and Espen Roysamb (2014), "Daily hassles and coping dispositions as predictors of psychological adjustment: A comparative study of young unaccompanied refugees and youth in the resettlement country", International Journal of Behavioral Development, Vol. 38(3), pp. 293-303.

Seydi, Ali Riza, (2014), “Turkiye'nin Suriyeli Siginmacilarin Egitim Sorununun Cozumune Yonelik Izledigi Politikalar", SDU Faculty of Arts and Sciences Journal of Social Sciences, 31, pp. 267-305. 
SFS 2005:429, The Act on Custodianship for Unaccompanied Minors.

SFS 2001:453, Social Services Act.

SFS 2001:937, Social Services Ordinance.

Sjögren, Anna and Yves Zenou (2007), "Vad förklarar invandrares integration på arbetsmarknaden? En teoriöversikt.”, Norrköping: The Immigrant Institute.

Socialstyrelsen (2016a), "Underlag för dialogmöte 2016-04-20 för projektet medicinsk åldersbedömning. Vetenskaplig utvärdering enligt Grade systemet av befintlig litteratur samt till förslag till ordnat införande av nya diagnostiska metoder."

Socialstyrelsen (2016b), "Åldersbedömning inom ramen för asylprocessen - en etisk analys."

Stabell Wiggen, Kjersti (2014), "Enslige mindreårige flyktninger, 2011. Arbeid, utdanning og inntekt", Statistics Norway, Report 2014/9.

Stabell Wiggen, Kjersti (2016), "Personer bosatt som enslige mindreårige flyktninger i perioden 1996-2013. Tre av fire i arbeid eller utdanning”, Statistics Norway, 7 January 2016. Steinbock, Daniel J. (1989), "The Admission of unaccompanied children into the United States", Yale Law and Policy Review, Vol. 7(1), pp. 137-200.

Stinchcomb, Dennis and Eric Hershberg (2014), "Unaccompanied Migrant Children from Central America. Context, Causes and Responses", CLAS Working Paper Series No. 7 , Washington D.C.

Stotz, Sabrina J., Thomas Elbert, Veronika Müller and Maggie Schauer (2015), “The relationship between trauma, shame, and guilt: findings from a community-based study of refugee minors in Germany", European Journal of Psychotraumatology, 2015, 6, 25863 http://dx.doi.org/10.3402/ejpt.v6.25863

Stretmo, Live and Melander, Charlotte (2013), "Får jag vara med? Erfarenheter från ensamkommande barn och ungdomar i Göteborgsregionen och arbetet med denna grupp", FoU i Väst, Rapportserie, 2:2013.

Summerfield, Derek (1999), “A critique of seven assumptions behind psychological trauma programmes in war-affected areas", Social Science \& Medicine, Vol. 48(10), pp. 1449-1462. 
Svendsen, Stina, Kristin Thorshaug and Berit Berg (2010), Boløsninger for enslige mindreårige flyktninger. Erfaringer fra to bykommuner, Trondheim: NTNU Samfunnsforskning AS.

Swedish National Agency for Education (2014), "Invandrare som påbörjat utbildning i svenska för invandrare.” Enheten för utbildningsstatistik, PM 27/05/2014.

Swedish National Agency for Education (2016), "Flest nyanlända elever i högstadie och gymnasieåldern."

Swedish National Audit Office (2009), “Tillsynen av överförmyndarna uppföljningsgranskning”, RiR 2009:31.

Swedish National Board of Health and Welfare (2013), "Socialtjänstens arbete med ensamkommande barn och ungdomar - en vägledning”, Stockholm.

Swedish National Board of Health and Welfare (2013a), "Ensamkommande barns och unga behov. En kartläggning”, Stockholm.

Swedish National Board of Health and Welfare (2015), "Ensamkommande barn och ungdomars försörjning”, PM 211/11/2015.

Swedish National Board of Health and Welfare (2016), "Ny placeringsform, stödboende för barn och unga 16-20 år”, Meddelandeblad Nr 1/2016.

The Finnish Immigration Service (2016), "First residence permits issued by the Finnish Immigration Service and persons who acquired Finnish citizenship in 2015".

The Swedish Migration Agency (2015), “Aktuellt om ensamkommande barn \& ungdomar", March 2015.

The Swedish Migration Agency (2016), “Aktuellt om ensamkommande barn \& ungdomar”, januari 2016.

UNHCR (2008), UNHCR Guidelines on Determining the Best Interests of the Child, Geneva: United Nations High Commissioner for Refugees.

UNHCR (2014), War's Human Cost: UNHCR Global Trends 2013, Geneva: United Nations High Commissioner for Refugees.

UNHCR (2015), Word at War: UNHCR Global Trends Forced Displacement in 2014, Geneva: United Nations High Commissioner for Refugees. 
UNHCR (2016a), http://data.unhcr.org/syrianrefugees/country.php?id=224. Geneva: United Nations High Commissioner for Refugees.

UNHCR (2016b), Global Trends. Forced Displacement in 2015, Geneva: United Nations High Commissioner for Refugees.

Vervliet, Marianne, Melinda A. Meyer Demott, Marianne Jakobsen, Eric Broekaert, Trond Heir and Ilse Derluyn (2014), "The mental health of unaccompanied refugee minors on arrival in the host country", Scandinavian Journal of Psychology, Vol. 55(1), pp. 33-37.

Vervliet, Marianne, Jan Lammertyn, Eric Broekaert and Ilse Derluyn (2015), “Longitudinal follow-up of the mental health of unaccompanied refugee minors", European Child \& Adolescent Psychiatry, Vol. 23(5), pp. 337-346.

Vervliet, Marianne, Cécile Rousseau, Eric Broekaert and Ilse Derluyn (2015), “Multilayered Ethics in Research Involving Unaccompanied Refugee Minors”, Journal of Refugee Studies, Vol. 28(4), pp.468-485.

Wade, Jim (2011), "Preparation and transition planning for unaccompanied asylum-seeking and refugee young people: A review of evidence in England", Children and Youth Services Review, Vol. 33, pp. 2414-2430.

Wallin, Anne-Marie and Gerd Ahlström (2005), "Unaccompanied young adult refugees in Sweden, Experiences of their life situation and well-being: a qualitative follow-up study", Ethnicity \& Health, Vol. 10(2), pp. 129-144.

Watters, Charles (2008), Refugee Children: Towards the Next Horizon, London: Routledge. Wernesjö, Ulrika (2011), “Unaccompanied asylum-seeking children: Whose perspective?” Childhood, Vol. 19(4), pp. 495-507.

Wilding, Jo and Marie-Bénédicte Dembour (2015), "Whose best interests? Exploring Unaccompanied Minors' Rights through the Lens of Migration and Asylum Processes (MinAs)", The UK National Report, University of Brighton.

Wimelius, Malin E., Joakim Isaksson, Malin Eriksson, Anders Hanberger and Mehdi Ghazinour (2012) Ensamkommande flyktingbarn och ungdomar - förutsättningar för mottagandet och kunskapsläget. Umeå: Umeå University. 
Wimelius, Malin E., Malin Eriksson, Joakim Isaksson and Mehdi Ghazinour (2016), "Swedish Reception of Unaccompanied Refugee Children - Promoting Integration?" International Migration \& Integration, DOI 10.1007/s12134-016-0472-2.

Zwi, Karen and Sarah Mares (2015), "Stories from unaccompanied children in immigration detention: A composite account", Journal of Paediatrics and Child Health, Vol 51, pp. 658662. 